\title{
A trophic characterization of intertidal consumers on Chilean rocky shores
}

\author{
Una caracterización trófica de los consumidores intermareales \\ en costas rocosas de Chile
}

\section{Patricio A. Camus ${ }^{1}$, Paulina A. Arancibia ${ }^{1,2}$ and M. Isidora Ávila-Thieme ${ }^{1,2}$}

\author{
${ }^{1}$ Departamento de Ecología, Facultad de Ciencias, Universidad Católica de la Santísima Concepción, Casilla 297, Concepción, \\ Chile.pcamus@ucsc.cl \\ ${ }^{2}$ Programa de Magister en Ecología Marina, Facultad de Ciencias, Universidad Católica de la Santísima Concepción, Casilla \\ 297, Concepción, Chile
}

\begin{abstract}
Resumen.- En los últimos 50 años, el rol trófico de los consumidores se convirtió en un tópico importante en la ecología de costas rocosas de Chile, centrándose en especies de equinodermos, crustáceos y moluscos tipificadas como herbívoros y carnívoros principales del sistema intermareal. Sin embargo, la dieta y comportamiento de muchos consumidores aún no son bien conocidos, dificultando abordar problemas clave relativos por ejemplo a la importancia de la omnivoría, competencia intra-e inter-específica o especialización individual. Intentando corregir algunas deficiencias, ofrecemos a los investigadores un registro dietario exhaustivo y descriptores ecológicos relevantes para 30 especies de amplia distribución en el Pacífico sudeste, integrando muestreos estacionales entre 2004 y 2007 en 4 localidades distribuidas en $1.000 \mathrm{~km}$ de costa en el norte de Chile. Basados en el trabajo de terreno y laboratorio, se presenta : (a) una matriz de consumidores-recursos generada por análisis de alta resolución del contenido intestinal de 6.377 individuos, incluyendo 222 presas (80\% identificadas a nivel de especie o género), (b) estimaciones de densidad, tamaño corporal (longitud y peso), amplitud dietaria (a nivel de individuo y especie), y diversidad intra-individual de los consumidores, (c) una ordenación nMDS de la similitud en composición dietaria entre consumidores, e información para cada consumidor sobre importancia relativa y frecuencia de ocurrencia de las presas más comunes. Considerando la amplia dieta omnívora y alta superposición de los consumidores, discutimos su potencial competitivo y el rol de la especialización individual en su carácter generalista, destacando la necesidad de reevaluar su comportamiento y efectos ecológicos en la comunidad intermareal.
\end{abstract}

Palabras clave: Dieta, amplitud de nicho, especialización individual, omnivoría, tamaño corporal

Abstract.- In the last 50 years, the trophic role of consumers has become a main research topic in the ecology of Chilean rocky shores, and in other regions. Several studies have typified species of echinoderms, crustaceans and mollusks as the most important herbivores and carnivores of intertidal assemblages. Unfortunately, little is known about the diet and behavior of many consumers, making difficult addressing key issues related to the importance of omnivory, intra- and inter-specific competition, or individual specialization. The goal of this paper is to fill some gaps in the available information and provide researchers with an exhaustive dietary analysis and relevant ecological descriptors for a suite of 30 consumer species distributed along the southeastern Pacific coast. Our data integrate information collected through seasonal samplings conducted between 2004 and 2007 at 4 localities distributed over 1,000 km of coast in northern Chile. Based on laboratory and field work analysis, we present: (a) a consumer-resource matrix obtained from high-resolution analyses of gut contents of 6,377 individuals, including 222 prey items ( $80 \%$ identified at species or genus level); (b) estimates of the density, body size (length and weight), diet width (at individual and species levels), and within-individual diversity of consumer species; (c) an nMDS ordination of the compositional similarity of consumers' diets, and information on the relative importance and occurrence frequency of the most common preys of each consumer. Based on the high frequency of omnivory and the high diet overlap among consumers, we discuss their potential for competition and the role of individual specialization in shaping their generalist character, highlighting the need to reappraise their behavior and ecological effects in the intertidal community.

Key words: Diet, niche width, individual specialization, omnivory, body size 


\section{INTRODUCTION}

During nearly 50 years of ecological research on nearshore ecosystems of Chile, few topics have received as much attention as the role and importance of rocky intertidal consumers in population and community processes (e.g., see Castilla \& Paine 1987, Santelices 1989, Fernández et al. 2000, Thiel et al. 2007). In this context, a suite of ecologically important invertebrates have been characterized as typical herbivores or carnivores of these systems, comprising some common species of echinoderms (sea stars, sea urchins) and crustaceans, but particularly a diverse group of molluscs including polyplacophorans, key-hole limpets, patellogastropopd limpets and snails.

Paradoxically, very little is known about the diet, feeding patterns and behavior of many of the consumers mentioned above (Camus et al. 2008, Aguilera 2011, Aguilera \& Navarrete 2011), as well as their trophic roles in the intertidal food web, and their response to climateoceanic variations (Camus 2008a). For instance, the trophic habits of 3 of the most conspicuous and largesized herbivores in Chile, the black sea urchin Tetrapygus niger and the chitons Enoplochiton niger and Acanthopleura echinata, were either virtually unknown or poorly documented a few years ago (see Navarrete et al. 2008, Sanhueza et al. 2008, Camus et al. 2012). Even for well-known species such as the only 2 keystone predators in this system, the sun star Heliaster helianthus and the muricid snail Concholepas concholepas, the possibility that they may engage in competition or intraguild predation was not suggested until recently (Navarrete \& Castilla 2003). In addition, researchers have long acknowledged the fact that herbivores regularly ingest animals in direct or indirect ways (e.g., Santelices \& Correa 1985, Santelices et al. 1986, Osorio et al. 1988, López et al. 2003), though only in recent years such phenomenon began to be examined in more detail. Current findings show that animal preys are indeed edible, palatable and digestible for common herbivores such as the chiton Chiton granosus or the key-hole limpets Fissurella limbata and Fissurella picta (Camus et al. 2009), and also that most herbivores make a widespread and consistent consumption of animals, including other herbivores (e.g., Aguilera 2005, Aguilera \& Navarrete 2007,
Camus et al. 2008; see review by Aguilera 2011). The available information thus challenges the trophic status of several species traditionally considered as herbivorous, posing key questions regarding the importance of physiological omnivory, and the roles of trophic omnivory (sensu Pimm \& Lawton 1978) and intraguild predation in Chilean intertidal food webs (Aguilera 2005, Camus et al. 2009, Camus et al. 2012). Furthermore, these trophic patterns are in many cases accompanied by sophisticated behaviors (Morales \& Camus 2005르, Morales et al. 2006², Aguilera \& Navarrete 2011), stressing the need of reappraising the role of these consumers in the community.

The new findings do show that the trophic versatility of Chilean consumers is much higher than previously thought. However, some chitons, fissurelids and sea urchins from other regions are known to display detritivorous, carnivorous or omnivorous habits (e.g., Latyshev et al. 2004, Hughes et al. 2005, Grall et al. 2006), or the ability to switch between herbivory and omnivory depending on environmental conditions (Latyshev et al. 2004). Thus, the importance of these findings lies not in the singularity of consumers but in a change of perspective in regard to their foraging and digestive capabilities, and also to the structure and complexity of Chilean intertidal food webs. If omnivory and intraguild predation are present, then food webs should be envisaged as having a higher connectivity involving both a greater number of trophic positions (therefore longer food chains) and a higher occurrence of trophic loops, all of which multiplies the presence of indirect effects and increases their importance in the community (see discussions by Navarrete et al. 2000, Camus et al. 2008, Camus et al. 2012).

A detailed knowledge of consumers' diets is then a necessary condition for exploring the scenario mentioned above because, as pointed by Polis (1991), increasing the sampling intensity and taxonomic resolution in diet analyses will inevitably reveal a higher food web complexity. In this regard, indirect diet analyses such as stable isotope ratios have the advantage of providing a temporally integrated view of consumption and assimilation (Layman \& Post 2008), but their taxonomic

\footnotetext{
${ }^{1}$ Morales K \& PA Camus. 2005. Conducta territorial de Scurria araucana (Mollusca: Patellogastropoda). XXV Congreso de Ciencias del Mar y XI Congreso Latinoamericano de Ciencias del Mar (COLACMAR), Valparaíso, Chile.

${ }^{2}$ Morales K, PA Camus \& B Santelices. 2006. Herbivoría y conducta agonística en el patelogastrópodo Scurria araucana. XV Reunión Anual de la Sociedad de Ecología de Chile, Universidad de La Serena, La Serena, Chile.
} 
resolution is not sufficient to examine particular interactions at the species level. In contrast, direct analyses (inspection of gut contents) are still the best option for achieving high resolution, but they only inform about recent consumptions (Layman \& Post 2008). This latter information could be improved by increasing the spatiotemporal extent of samplings, though at the price of increasing the cost of time and resources. Additionally, direct observations such as gut content analyses usually deal with fragmented or partially digested preys which are not easily identifiable at low taxonomic levels, and their quality depends strongly on taxonomic expertise (Camus et al. 2008). However, low taxonomic resolution bears a high cost, as the fail to identify a high fraction of preys forces their aggregation into coarse or higher-level categories, conveying a significant loss of information and causing that many direct or indirect interactions remain undetected or confounded.

The available data for Chilean consumers show, unfortunately, that information gaps, taxonomic aggregation and/or limited spatiotemporal extent of samplings are rather the rule than the exception (e.g., see Sanhueza et al. 2008, Camus et al. 2012). Consequently, we aim to improve the available knowledge by capitalizing the information collected in a prior community survey conducted seasonally from 2004 to 2007 at 4 rocky intertidal localities in northern Chile. As a parallel goal of this survey, we carried out a systematic collection of individuals of the main consumer species present at each locality for obtaining diet information based on direct analyses of gut contents, making a particular effort to identify prey items at the lowest possible level. Therefore, we herein focus on the diet and basic ecological attributes of a diverse assemblage of invertebrates differing in body size, ecological importance and spatiotemporal occurrence, although most of them are common in at least some areas within or outside northern Chile, and all have geographical ranges extending toward Peru and/or central-southern Chile. The main goals of this paper are: (a) to make available to researchers a detailed account of the richness and composition of preys used by a suite of 30 consumer species widespread along the southeast Pacific coast, in order to fill some important gaps in the trophic ecology of Chilean rocky intertidal shores, and (b) to provide reliable information on the high complexity of these food webs, emphasizing the need of reappraising the behavior and trophic position of consumers in the community, as well as the trophic relationships among intertidal organisms.

\section{MAterials AND METHODS}

We selected 4 localities (Fig. 1) distributed over $~ 1,000$ $\mathrm{km}$ of coast in northern Chile: Lagunillas (3006'14'”S, $71^{\circ} 22^{\prime} 57^{\prime} \mathrm{W}$; south of Coquimbo), Caleta Angosta

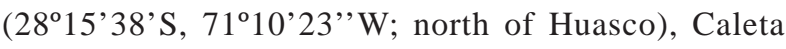

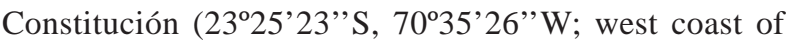

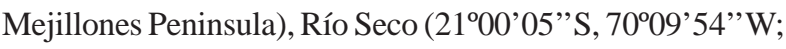
south of Iquique). The 4 assemblages represent a characteristic type of rocky intertidal community found on wave-exposed shores in north-central Chile, and they shared a similar taxonomic composition and ecological structure (see Fernández et al. 2000, Broitman et al. 2001, Thiel et al. 2007, Camus et al. 2008). However, Caleta Constitución and Lagunillas locate at or near to prominent upwelling centres at $23^{\circ}$ and $30^{\circ} \mathrm{S}$, respectively (Camus \& Andrade 1999, Thiel et al. 2007), likely receiving higher nutrient loads throughout the year.

Sites were sampled seasonally between winter 2004 and autumn 2007, generating a total of 48 community samples (4 sites $\mathrm{x} 12$ seasons). We indicate both the seasons (pooling localities) and the percentage of samplings in which each species occurred. All the 4 localities were sampled during a same low-tide cycle each season, using the same sampling design, grain and extent in order to minimize spatial biases and account for the patchiness of food resources. At each locality and season,

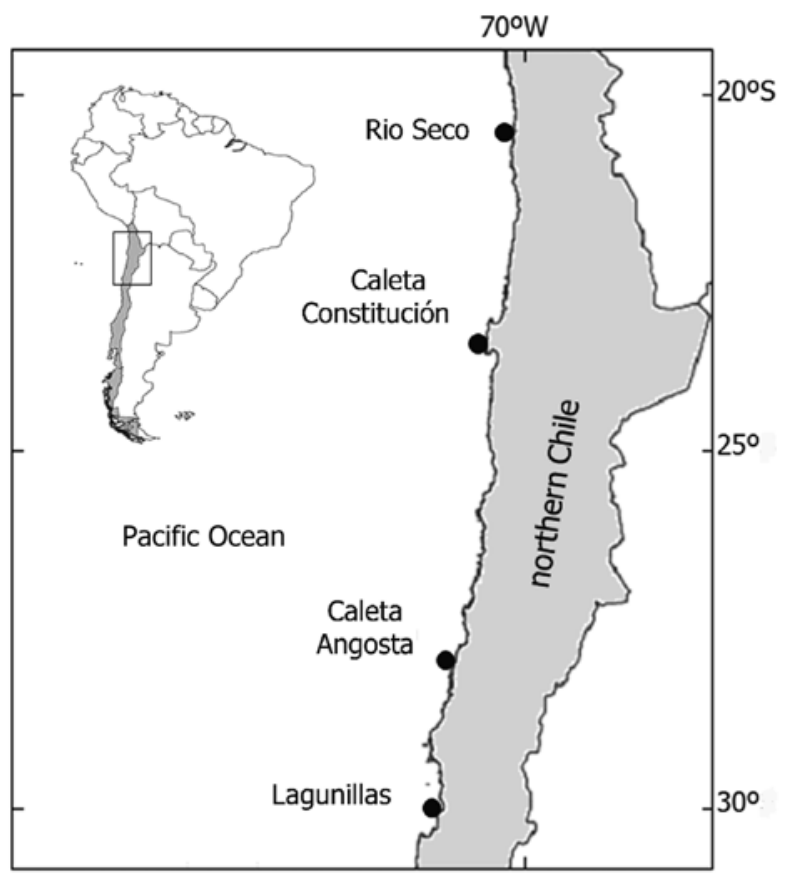

Figure 1. Location of study sites in northern Chile / Ubicación de los sitios de estudio en el norte de Chile 
we assessed a $150 \mathrm{~m}$ stretch of coast line using 45 quadrats $\left(0.25 \mathrm{~m}^{2}\right)$ distributed at the high, mid and low intertidal zones of 5 georeferenced blocks (15 m length) spaced every $15 \mathrm{~m}$, with 9 quadrats per block (three per zone) spaced $5 \mathrm{~m}$ horizontally and $1.5 \mathrm{~m}$ vertically. While consumer densities were recorded in all the 45 quadrats, we present estimates that use only the quadrats in which individuals were present (zero-values omitted), in order to better reflect their spatial occurrence in the field (detailed descriptions of within- and between-site variability will be presented elsewhere). The vertical distribution of species was quantified as the relative percentage of low-, mid- and high-zone quadrats in which they occurred. For diet analyses, individuals were collected randomly (at daytime) from different tidal levels at the 5 sampling blocks, and then injected with and stored in $8 \%$ formaldehyde for preserving gut contents. Collected individuals were mainly adults (including different sizes), not classified by tidal level. We estimated that a sample of 10 individuals may allow recording $>85 \%$ of the population diet (Camus et al. 2008, 2012), but in order to minimize sampling impacts, we managed effort by taking smaller numbers when species occurred in lower abundances, and thus collected an average of $9.4 \pm 0.2$ (SE) individuals per species, site and season. The maximum length and dry biomass (oven dried to constant weight at $70^{\circ} \mathrm{C}$ ) of collected individuals were recorded in the laboratory.

Gut contents analyses were done on a per-individual basis, and prey items were identified at the lowest possible level. In order to reduce errors and biases, the taxonomic work was conducted by previously trained researchers who used the same criteria, procedures and equipment. When possible, we provide full binomial names for consumers and preys, updated by following the databases WoRMS (World Register of Marine Species; Appeltans et al. 2013) and AlgaeBase (Guiry \& Guiry 2013). We note that prey items informed as 'Genus sp.' correspond to species which could be individualized but not identified, while 'Genus spp.' involve two or more species of the same genus which could not be discriminated among. In particular, due to the trophic importance of Ulva and Enteromorpha, and a recent taxonomic revision of their species, we made a distinction between 'Ulva spp.' and 'Ulva spp. (ex Enteromorpha)', as these latter species are well known to researchers, and their morphological differences with Ulva could be important in consumers' choice.

From the above information, we characterized the trophic niche width of consumers based on 3 simple descriptors: the average number of prey items recorded per individual, the total number of prey items per species (pooling individual data), and the proportion (\%) between individual and species prey ranges $(100 \%$ indicates that individuals use the full resource spectrum of the species). The former 2 variables allow to compare the specialist or generalist character of individuals and species, and the latter estimates the within-individual component of niche width (Bolnick et al. 2002), where decreasing values reflect increasing degrees of individual specialization (i.e., low values represent generalist species formed by specialist individuals). Complementarily, we shown the full list of the algal and animal prey ingested by consumer species, along with the occurrence frequency of their most important prey, estimated as the proportion of times in which a prey was found in a sample of $\mathrm{N}$ digestive tracts. Occurrence frequencies cannot inform on the numeric or gravimetric importance of prey in gut contents, but as an indirect estimate of consumption intensity they are useful to make inferences on the trophic activity of consumers. Finally, it provides a graphical representation of the similarity among consumers based on an ordination analysis of the taxonomic composition of their diets, generated by non-metric multidimensional scaling by means of the Jaccard's index.

\section{Results}

\section{GENERAL INFORMATION}

The diet data presented in this paper were based on 6,377 individuals belonging to 16 genera and 30 species of the phyla Echinodermata (4 species) and Mollusca (26 species), including 6 polyplacophorans, 6 key-hole limpets, 8 patellogastropod limpets, 2 heterobranch pulmonate gastropods, 3 turbinid gastropods, one calyptraeid gastropod, 2 urchins and 2 starfish (see Table 1). The 2 starfish were essentially carnivorous, while the remaining 28 species were trophic omnivores (feeding on 2 or more trophic levels) with mostly herbivorous diets including varying proportions of animal items (see Table 2). Throughout the study, was collected an average of 213 individuals per species, although the totals were highly variable among species in correspondence with their rarity or commonness in the field, ranging from 3 (Fissurella cumingi) to 508 (Tegula atra). Field and laboratory estimations for the 30 species are summarized in Table 1 and described below including correlation analyses (Spearman's coefficient, $\mathrm{r}_{\mathrm{s}}$ ) among selected 
variables. We remark that the length and biomass of consumers were measured only for individuals collected for diet analyses, and while such estimates may bear direct relationships with our trophic estimates, they may not accurately represent the actual body size of field populations.

\section{ECOLOGICAL DESCRIPTORS}

The mean local population density of species ranged from 4 (Tonicia elegans) to 313.6 (Prisogaster niger) individuals $\mathrm{m}^{-2}$ (Table 1). However, we lack information for 3 species (Chiton magnificus, F. cumingi and Scurria scurra) which were collected manually for diet analyses but remained undetected in our sampling quadrats. In the field, the patchy distribution of most species was better reflected by the density ranges estimated from their occurrence in single quadrats. While in all cases the minimum density was 4 individuals $\mathrm{m}^{-2}$, the maximum density was $\geq 40 \mathrm{~m}^{-2}$ for $54 \%$ of species and $\geq 100 \mathrm{~m}^{-2}$ for $20 \%$ of species, though reaching values as high as 3,600 $\mathrm{m}^{-2}$ and $4,840 \mathrm{~m}^{-2}$ for $P$. niger and T. atra, respectively. Interestingly, the mean local density of consumers was negatively correlated with their length $\left(\mathrm{r}_{\mathrm{s}}=-0.49, P=\right.$ $0.0060, \mathrm{n}=27$ ), though showing no significant associations with other variables. Albeit the 27 sampled species tended to be more frequent at one particular intertidal zone (Table 1), 18 of them (67\%) occurred through the entire vertical range, 7 (26\%) at 2 of the 3 zones (mainly the low and mid zones), and 2 (7\%; Tegula tridentata and T. elegans) at the low zone only, suggesting a widespread effect of the consumer assemblage on the community.

The body size of consumer species exhibited strong differences (Table 1), reaching up to 2 and 4 orders of magnitude in length and biomass, respectively, although these two variables were highly correlated $\left(\mathrm{r}_{\mathrm{s}}=0.91, P<\right.$ $0.0001, \mathrm{n}=30$ ). Both in length and biomass, the largest consumer was by far the sun star $H$. helianthus, followed closely by the polyplacophorans A. echinata and E. niger, while the smallest one was the shell-less pulmonate sea slug $O$. marginata.

Pooling our 48 site-by-season samplings, the assemblage of 30 consumers as a whole ingested a total number of 222 prey items, although the contribution of species to this total was markedly different (see Table 1). The average number of prey items per individual ranged from 1.4 (Stichaster striatus) and 3.3 (Scurria zebrina) to 17.7 (F. cumingi) and 17.8 (Loxechinus albus), while the total number at the species level ranged from 21 (S. scurra) and 26 (S. zebrina) to 147 (L. albus) and 151 (T. niger). At the species level, most consumers exhibited a wide diet spectrum, as $43 \%$ of species had diet ranges $\geq 60$ prey, while not less than 6 species consumed each $\geq 110$ prey, equivalent to $\geq 50 \%$ (and up to $68 \%$ in the sea urchin $L$. albus) of the assemblage's range (Table 1), which points to a high level of diet overlap and functional redundancy at the assemblage level. In addition, the number of prey at individual and species levels were positively associated $\left(\mathrm{r}_{\mathrm{S}}=0.54, P=0.0023, \mathrm{n}=30\right)$, suggesting that the diet width of species tends to reflect the generalist or specialist character of their individuals, although the moderate strength of the correlation also indicates that this match is either partial or different among species. Indeed, the within-individual component of niche width (Table 1) was very low (average: $26.2 \%$ ) ranging from $4.4 \%$ (S. striatus) to $59.0 \%$ (F. cumingi), and individuals from 15 species consumed less than $10 \%$ of the species' diet spectrum (and less than 20\% in 26 species). Albeit this result suggests an important degree of individual specialization in contrast with the apparent generalist character of most species, it should be interpreted with caution because the within-individual component was negatively associated with both the number of digestive tracts analyzed per species $\left(\mathrm{r}_{\mathrm{s}}=-0.85, P<0.0001, \mathrm{n}=30\right)$ and the total number of prey per species $\left(\mathrm{r}_{\mathrm{S}}=-0.58, P=0.0008\right.$, $n=30$ ). While these correlations show an obvious effect of sampling size, and our data may include sampling biases to some extent, such effect would be largely due to the rarity or commonness of species, which determined the final sampling size, and also to the high taxonomic resolution of diet analyses which increased the total number of items as more samples were available. Table 1 shows the large differences in occurrence among species in the 48 site-by-season samplings, varying from 2.1\% ( $F$. cumingi) to $95.8 \%$ (E. niger), with 14 species (47\%) occurring in at least $50 \%$ of samplings and 10 species (33\%) in less than 25\%. In addition, while several species occurred through all seasons of the year at one or more sites, others were detected irregularly during the study (e.g., Fissurella costata, Chiton cumingsii or Tegula tridentata), or only during short periods (e.g., F. picta or Onchidella marginata). In this context, therefore, species with higher occurrence and larger sample size (e.g., C. granosus or T. atra in Table 1) may tend to show higher diet width and higher individual specialization than rare species (e.g., F. cumingi or F. picta). However, there are also species that deviate from this trend, exhibiting a comparatively high (e.g., C. magnificus or F. nigra) or low (e.g., P. niger or S. striatus) diet width while having a 
Table 1. Ecological descriptors obtained for a suite of $\mathbf{3 0}$ rocky intertidal consumers studied in northern Chile. Columns: species; mean density ( \pm SD) and range estimated in the field; vertical distribution, shown as the relative occurrence (\%) of individuals at low (L), mid (M) and high $(H)$ intertidal zones; mean body size $( \pm \mathrm{SE}$ ) measured as maximum length and dry weight; total number of digestive tracts (NDT) analyzed per species, including the percentage of empty tracts (ET \%, in parentheses) when detected; mean number ( \pm SE) of prey items per individual (MPI); total number of prey items per species (TPS); within-individual component of diet width (WIC), estimated as the quotient MPI/TPS (\%); occurrence percentage of consumers in 48 site-by-season samplings (PS \%), including the seasons (Se, in parentheses) in which they were present throughout the study (sites pooled; seasons numbered correlatively from 1: Fall 2004, to 12: Fall 2007) / Información ecológica básica para un conjunto de 30 consumidores intermareales rocosos estudiados en el norte de Chile. Columnas: densidad media ( \pm DE) y rango estimados en terreno; distribución vertical, mostrado como la ocurrencia relativa (\%) de individuos en las zonas intermareales baja $(\mathrm{L})$, media $(\mathrm{M})$ y alta $(\mathrm{H})$; tamaño corporal medio ( $\pm \mathrm{EE}$ ) medido como longitud máxima y peso seco; número total de tractos digestivos (NDT) analizados por especie, incluyendo el porcentaje de tractos vacíos (\% ET, entre paréntesis) cuando fueron detectados; número promedio ( $\pm \mathrm{EE}$ ) de ítems presa por individuo (MPI); número total de ítems presa por especie (TPS); componente intra-individual de la amplitud de dieta (WIC), estimado como el cuociente MPI/TPS (\%); porcentaje de ocurrencia de los consumidores en 48 muestreos sitio x estación (PS $\%$ ), incluyendo las estaciones (Se, entre paréntesis) en las que estuvieron presentes durante el estudio (sitios agrupados; estaciones numeradas correlativamente desde 1: otoño 2004, a 12: otoño 2007)

\begin{tabular}{|c|c|c|c|c|c|c|c|c|c|c|}
\hline Consumer species & $\begin{array}{c}\text { Density } \\
{\text { (ind. } \mathrm{m}^{-2} \text { ) }}^{\text {a }}\end{array}$ & $\begin{array}{l}\text { Density range } \\
\text { (ind. } \mathrm{m}^{-2} \text { ) }\end{array}$ & $\begin{array}{c}\text { Vertical } \\
\text { distribution (\%): } \\
\mathrm{L}-\mathrm{M}-\mathrm{H}\end{array}$ & $\begin{array}{l}\text { Length } \\
(\mathrm{cm})\end{array}$ & $\begin{array}{l}\text { Dry weight } \\
\text { (g) }\end{array}$ & $\begin{array}{c}\text { NDT } \\
\text { (ET \%) }\end{array}$ & MPI & TPS & WIC (\%) & PS $\%(\mathrm{Se})$ \\
\hline Acanthopleura echinata (Barnes, 1824) & $6.8 \pm 1.4$ & $4-40$ & $91-9-0$ & $12.7 \pm 0.3$ & $28.6 \pm 1.4$ & 379 & $9.8 \pm 0.2$ & 113 & 8.7 & $\begin{array}{c}91.7 \\
(1-12)\end{array}$ \\
\hline Chiton granosus (Frembly, 1827) & $7.3 \pm 1.6$ & $4-52$ & $35-51-14$ & $5.0 \pm 0.1$ & $3.3 \pm 0.2$ & 444 & $6.2 \pm 0.1$ & 76 & 8.2 & $\begin{array}{c}83.3 \\
(1-12)\end{array}$ \\
\hline Chiton magnificus (Deshayes, 1827) & NS & NS & NS & $9.7 \pm 1.0$ & $21.9 \pm 3.6$ & 27 & $8.1 \pm 0.8$ & 42 & 19.3 & $\begin{array}{c}10.4 \\
(6-8,12)\end{array}$ \\
\hline Chiton cumingsii (Frembly, 1827) & $10 \pm 5.1$ & $4-80$ & $88-12-0$ & $3.9 \pm 0.1$ & $1.2 \pm 0.1$ & $\begin{array}{c}92 \\
(2.2)\end{array}$ & $5.3 \pm 0.3$ & 44 & 12.0 & $\begin{array}{c}29.2 \\
(6-7,9-12)\end{array}$ \\
\hline Enoplochiton niger (Barnes, 1824) & $10.2 \pm 2.4$ & $4-52$ & $73-27-0$ & $12.4 \pm 0.2$ & $30.2 \pm 0.9$ & $\begin{array}{l}492 \\
(0.2)\end{array}$ & $8.7 \pm 0.2$ & 119 & 7.3 & $\begin{array}{c}95.8 \\
(1-12)\end{array}$ \\
\hline Tonicia elegans (Frembly 1828) & $4.0 \pm 0.0$ & $4-4$ & $100-0-0$ & $5.1 \pm 0.3$ & $3.0 \pm 0.4$ & 63 & $5.7 \pm 0.3$ & 34 & 16.8 & $\begin{array}{c}35.4 \\
(6-12)\end{array}$ \\
\hline Fissurella costata (Lesson, 1831) & $7.3 \pm 1.9$ & $4-52$ & $92-6-1$ & $4.9 \pm 0.1$ & $13.3 \pm 1.6$ & 84 & $9.2 \pm 0.5$ & 60 & 15.3 & $\begin{array}{c}22.9 \\
(6-8,10,12)\end{array}$ \\
\hline Fissurella crassa (Lamarck, 1822) & $5.6 \pm 0.9$ & $4-24$ & $32-60-8$ & $4.6 \pm 0.1$ & $9.7 \pm 0.4$ & 427 & $9.6 \pm 0.2$ & 111 & 8.6 & $\begin{array}{c}89.6 \\
(1-12)\end{array}$ \\
\hline Fissurella cumingi (Reeve, 1849) & NS & NS & NS & $5.8 \pm 0.3$ & $13.3 \pm 2.1$ & 3 & $17.7 \pm 4.1$ & 30 & 59.0 & $\begin{array}{l}2.1 \\
(8)\end{array}$ \\
\hline Fissurella nigra (Lesson, 1831) & $6.0 \pm 1.4$ & $4-20$ & $58-17-25$ & $5.8 \pm 0.4$ & $18.1 \pm 0.1$ & 28 & $11.7 \pm 0.6$ & 49 & 23.9 & $\begin{array}{l}10.4 \\
(6-8)\end{array}$ \\
\hline Fissurella picta (Gmelin, 1791) & $5.5 \pm 0.8$ & $4-20$ & $90-10-0$ & $4.8 \pm 0.2$ & $11.3 \pm 1.8$ & 29 & $9.9 \pm 0.6$ & 35 & 28.3 & $\begin{array}{c}12.5 \\
(9,11)\end{array}$ \\
\hline Scurria araucana (d'Orbigny, 1841) & $11.4 \pm 3.6$ & $4-168$ & $19-52-29$ & $1.79 \pm 0.04$ & $0.8 \pm 0.1$ & $\begin{array}{l}264 \\
(1.9)\end{array}$ & $4.4 \pm 0.2$ & 62 & 7.1 & $\begin{array}{c}66.7 \\
(1-12)\end{array}$ \\
\hline Scurria ceciliana (d'Orbigny, 1841) & $34.8 \pm 15.4$ & $4-440$ & $14-36-50$ & $1.3 \pm 0.1$ & $0.5 \pm 0.1$ & 199 & $4.2 \pm 0.2$ & 49 & 8.6 & $\begin{array}{c}50 \\
(1-11)\end{array}$ \\
\hline Scurria plana (Philippi, 1846) & $6.8 \pm 1.8$ & $4-56$ & $70-19-11$ & $1.33 \pm 0.04$ & $0.26 \pm 0.03$ & 69 & $3.6 \pm 0.2$ & 31 & 11.6 & $\begin{array}{c}27.1 \\
(6-11)\end{array}$ \\
\hline Scurria scurra (Lesson, 1841) & NS & NS & NS & $1.6 \pm 0.1$ & $0.8 \pm 0.1$ & $\begin{array}{c}40 \\
(15)\end{array}$ & $3.5 \pm 0.3$ & 21 & 16.7 & $\begin{array}{l}12.5 \\
(6-7)\end{array}$ \\
\hline Scurria variabilis (G.B. Sowerby I, 1839) & $8.3 \pm 2.2$ & $4-68$ & $27-54-19$ & $1.58 \pm 0.04$ & $0.49 \pm 0.04$ & 205 & $5.0 \pm 0.2$ & 58 & 8.6 & $\begin{array}{c}43.8 \\
(6-11)\end{array}$ \\
\hline Scurria viridula (Lamarck, 1822) & $7.8 \pm 1.9$ & $4-60$ & $25-43-31$ & $3.0 \pm 0.1$ & $4.2 \pm 0.3$ & $\begin{array}{l}497 \\
(1.8)\end{array}$ & $5.1 \pm 0.1$ & 74 & 6.9 & $\begin{array}{c}87.5 \\
(1-12)\end{array}$ \\
\hline Scurria zebrina (Lesson, 1831) & $7.3 \pm 1.5$ & $4-28$ & $28-54-19$ & $1.3 \pm 0.1$ & $0.3 \pm 0.1$ & 34 & $3.3 \pm 0.4$ & 26 & 12.7 & $\begin{array}{l}16.7 \\
(5-8)\end{array}$ \\
\hline Siphonaria lessonii (Blainville, 1827) & $20.1 \pm 6.3$ & $4-236$ & $25-12-62$ & $1.28 \pm 0.02$ & $0.25 \pm 0.01$ & 375 & $4.5 \pm 0.1$ & 64 & 7.0 & $\begin{array}{c}68.8 \\
(1-12)\end{array}$ \\
\hline Prisogaster niger (Wood, 1828) & $313.6 \pm 147.2$ & $4-3600$ & $79-20-1$ & $0.88 \pm 0.02$ & $0.42 \pm 0.02$ & 216 & $3.5 \pm 0.2$ & 37 & 9.5 & $\begin{array}{c}39.9 \\
(1-9,11)\end{array}$ \\
\hline Tegula atra (Lesson, 1830) & $233.6 \pm 136.2$ & $4-4840$ & $85-14-1$ & $2.9 \pm 0.1$ & $10.7 \pm 0.6$ & 508 & $6.1 \pm 0.1$ & 81 & 7.5 & $\begin{array}{c}91.7 \\
(1-12)\end{array}$ \\
\hline Tegula tridentata (Potiez \& Michaud, 1838) & $6.7 \pm 1.0$ & $4-12$ & $100-0-0$ & $5.1 \pm 0.3$ & $3.0 \pm 0.4$ & $\begin{array}{c}74 \\
(1.4)\end{array}$ & $4.7 \pm 0.2$ & 35 & 13.4 & $\begin{array}{c}16.7 \\
(6-8,10-11)\end{array}$ \\
\hline Trochita trochiformis (Born, 1778) & $8.0 \pm 2.0$ & $4-20$ & $57-43-0$ & $2.04 \pm 0.08$ & $2.0 \pm 0.1$ & 55 & $4.5 \pm 0.2$ & 36 & 12.5 & $\begin{array}{c}18.8 \\
(7-11)\end{array}$ \\
\hline Loxechinus albus (Molina, 1782) & $10.3 \pm 3.3$ & $4-72$ & $92-3-4$ & $5.8 \pm 0.1$ & $24.4 \pm 1.0$ & $\begin{array}{l}220 \\
(0.5)\end{array}$ & $17.8 \pm 0.4$ & 147 & 12.1 & $\begin{array}{c}50 \\
(6-12)\end{array}$ \\
\hline Tetrapygus niger (Molina, 1782) & $17.9 \pm 5.2$ & $4-100$ & $88-12-1$ & $5.2 \pm 0.1$ & $20.9 \pm 0.6$ & 462 & $10.8 \pm 0.3$ & 151 & 7.2 & $\begin{array}{c}93.8 \\
(1-12)\end{array}$ \\
\hline Stichaster striatus (Müller \& Troschel, 1840) & $6.4 \pm 1.0$ & $4-20$ & $92-8-0$ & $11.1 \pm 0.5$ & $10.4 \pm 0.7$ & $\begin{array}{l}182 \\
(22)\end{array}$ & $1.4 \pm 0.1$ & 32 & 4.4 & $\begin{array}{c}50 \\
(1-12)\end{array}$ \\
\hline Heliaster helianthus (Lamarck, 1816) & $5.6 \pm 1.1$ & $4-60$ & $46-36-18$ & $15.7 \pm 0.2$ & $59.2 \pm 2.2$ & 448 & $8.2 \pm 0.6$ & 83 & 9.9 & $\begin{array}{c}91.7 \\
(1-12)\end{array}$ \\
\hline
\end{tabular}


smaller or larger sample size, respectively. Thus, some important fraction of the observed differences in diet width and individual specialization may likely reflect species-specific attributes rather than sampling effects, and comparisons among species should be made carefully.

Interestingly, the body size of consumers, considered either as biomass (dry weight) or length, showed a positive association with the number of consumed prey (diet width) both at the individual and species level, although this relationship was better reflected by the stronger correlation between biomass and diet width (for individuals: $\mathrm{r}_{\mathrm{s}}=0.76, P<0.0001$; for species: $\mathrm{r}_{\mathrm{s}}=0.57, P=$ $0.0011 ; n=30)$. The fact that empty digestive tracts were notably infrequent suggests that diet data bear small biases, and provides additional support for the above relationship. Indeed, individuals lacking gut contents occurred in only nine species (see Table 1), particularly in S. scurra (15\%) and S. striatus (22\%), but reaching very low proportions in the remaining seven (0.2 to $2.2 \%$ ).

\section{DiET COMPOSITION}

Table 2 shows the full list of prey ingested by each consumer species, totalizing 222 items corresponding to
101 algae (45.5\%) and 121 animals (54.5\%), from which $174(78.4 \%)$ were identified at the level of species (54.5\%) or genus (23.9\%). We indicate the fraction of sites in which each prey was consumed, intended to reflect its spatial incidence in gut contents. However, non-consumed preys were not necessarily absent in the field, and the above fraction should thus not be interpreted as occurrence in the study sites, except in the case of prey consumed in all the 4 sites (therefore present at all sites). Nonetheless, this latter case occurs 462 times in Table 2, often repeated in different columns (consumers) from the same row (prey), indicating not only that many prey were common but also that many consumers shared the same prey at all sites. Indeed, the sum of the total number of prey per species in Table 1 equals 1,874 items, which contains $>8.4$ times the grand total of 222 items ingested by the entire assemblage, suggesting an important dietary redundancy among consumers.

After an nMDS ordination based on the composition of consumer diets (Fig. 2), the 28 trophic omnivores tended to form a single heterogeneous cluster, though separated from the carnivore starfish $H$. helianthus and $S$. striatus which in turn located far from each other, likely in part by the higher ingestion (whether casual or not) of algae by $H$. helianthus (Table 2) and our smaller sample size for $S$.

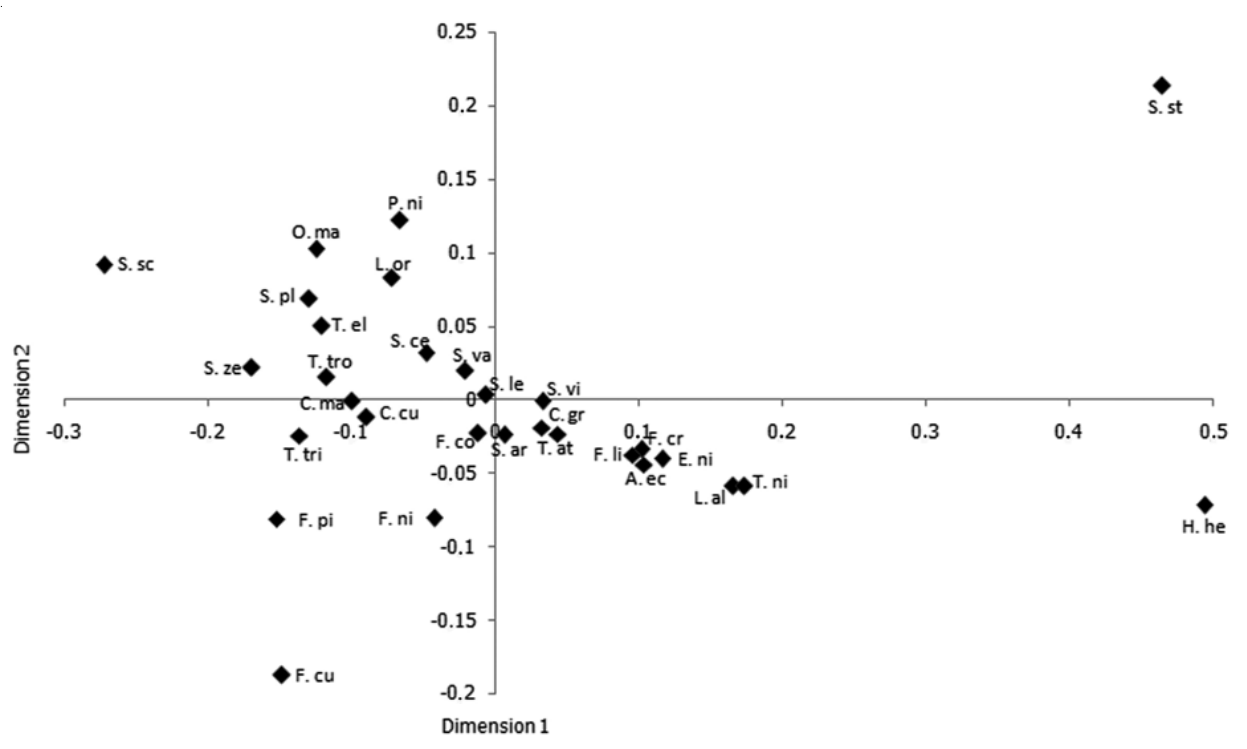

Figure 2. Multivariate ordination (nMDS, stress: 0.116 ) of rocky intertidal consumers based on the similarity (Jaccard's index) of the taxonomic composition of their diets. Species names are abbreviated by the initial letter of the genus and the first two letters of the specific name (see full binomial names in Table 1) / Ordenación multivariada (nMDS, estrés: 0,116) de los consumidores intermareales rocosos basada en la similitud (índice de Jaccard) de la composición taxonómica de sus dietas. Los nombres de las especies fueron abreviados usando la inicial del género y las dos primeras letras del nombre específico (ver los nombres binomiales completos en la Tabla 1) 

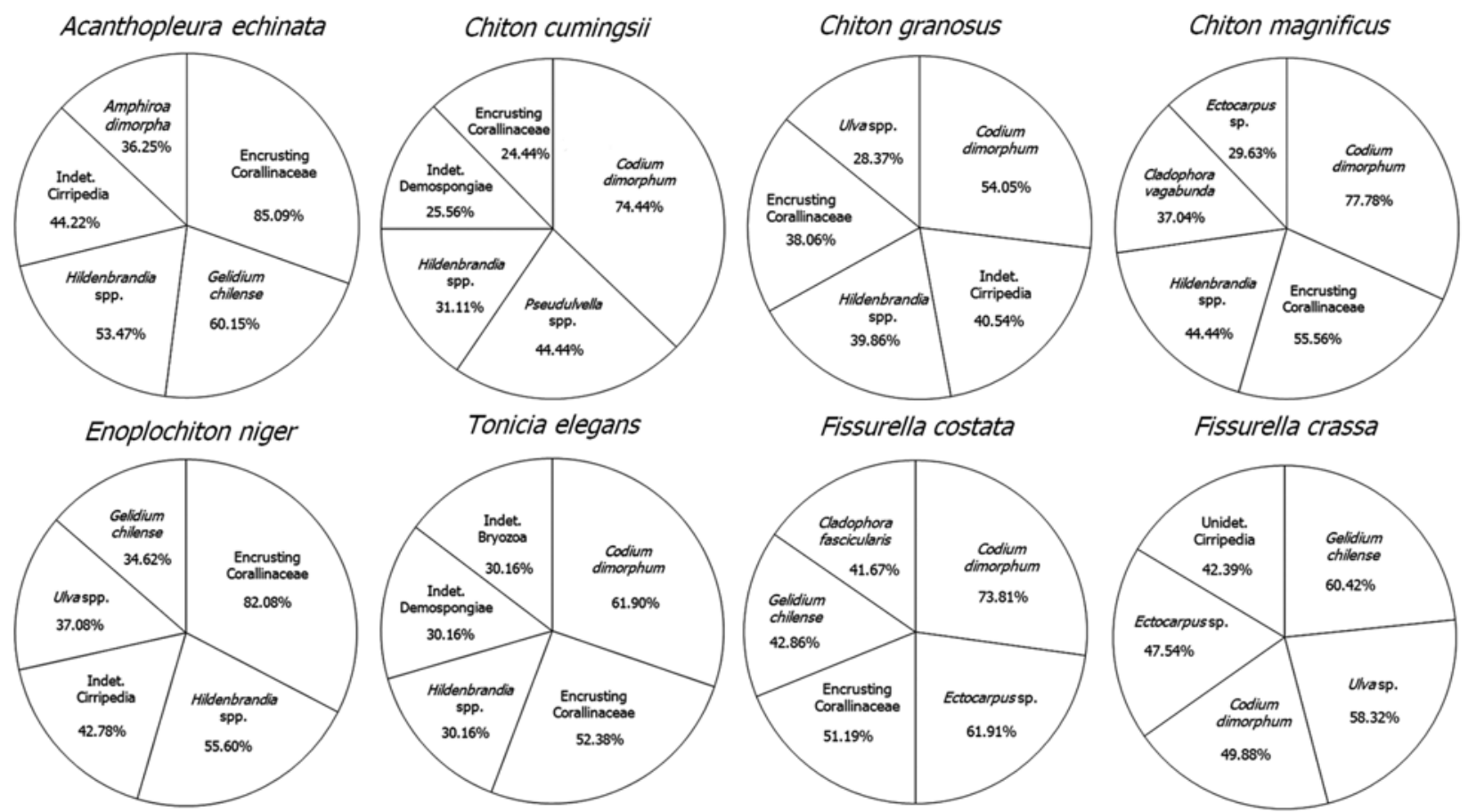

Tonicia elegans

Fissurella costata

Fissurella crassa
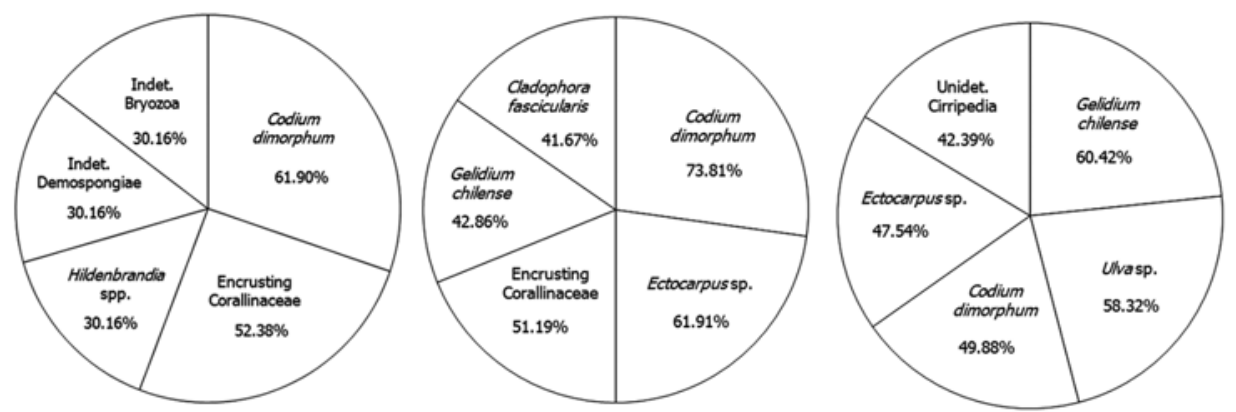

Fissurella cumingi

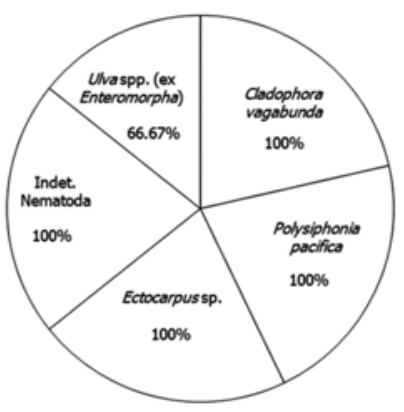

Fissurella limbata

Fissurella nigra

Fissurella picta
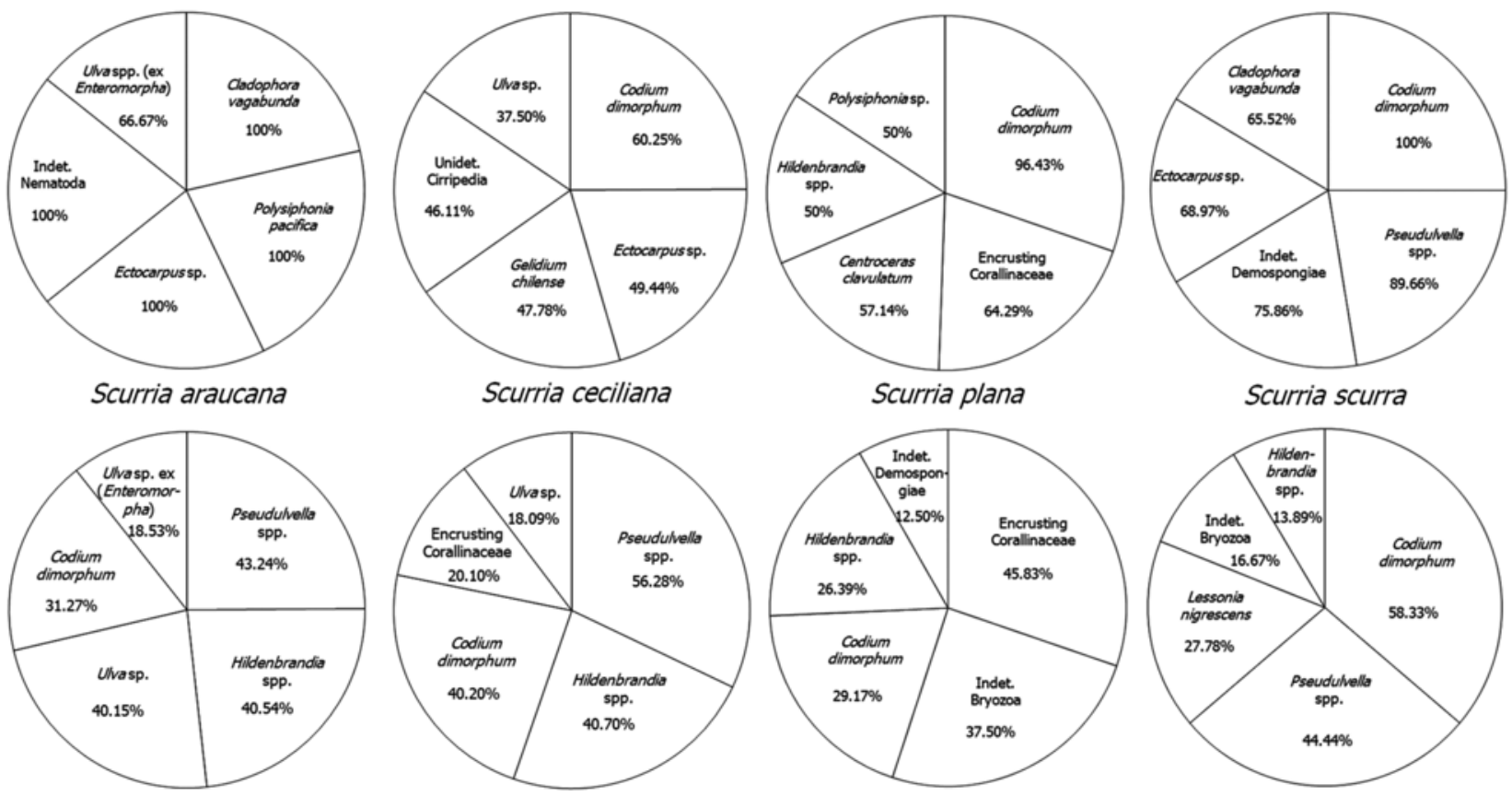
Scurria variabilis

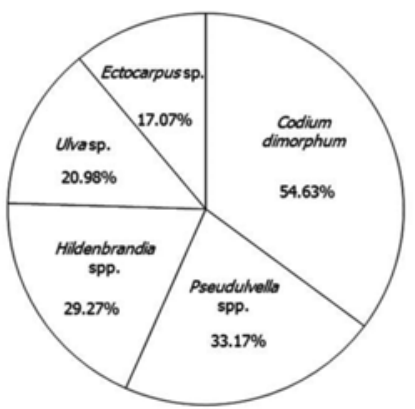

Lottia orbigny

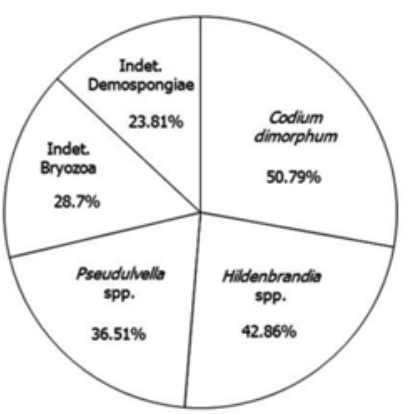

Scurria viridula

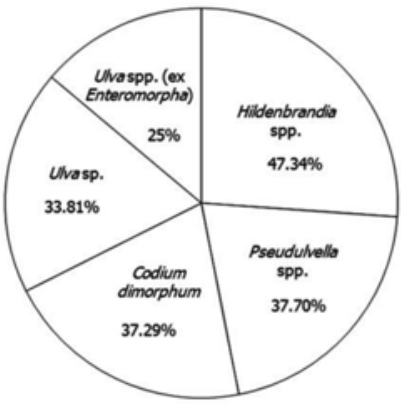

Onchidella marginata
Scurria zebrina

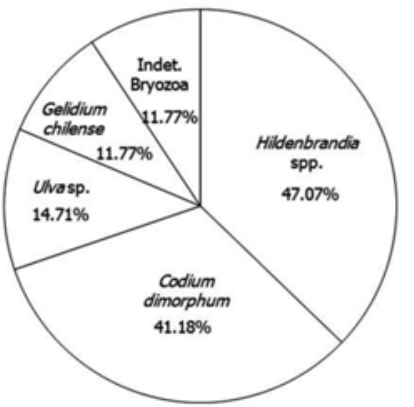

Prisogaster niger
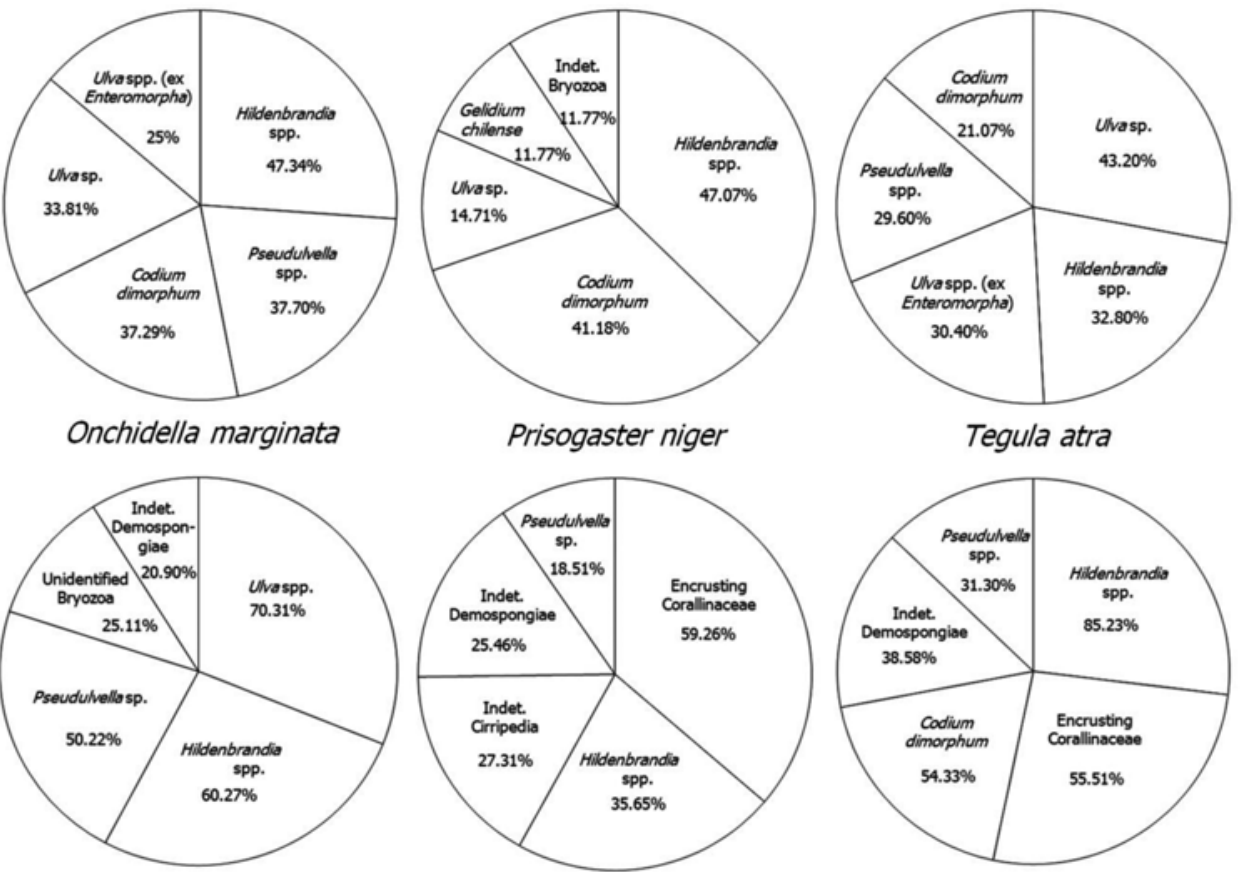

Tegula atra

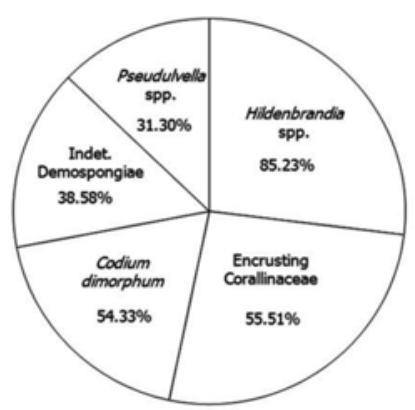

Tegula tridentata
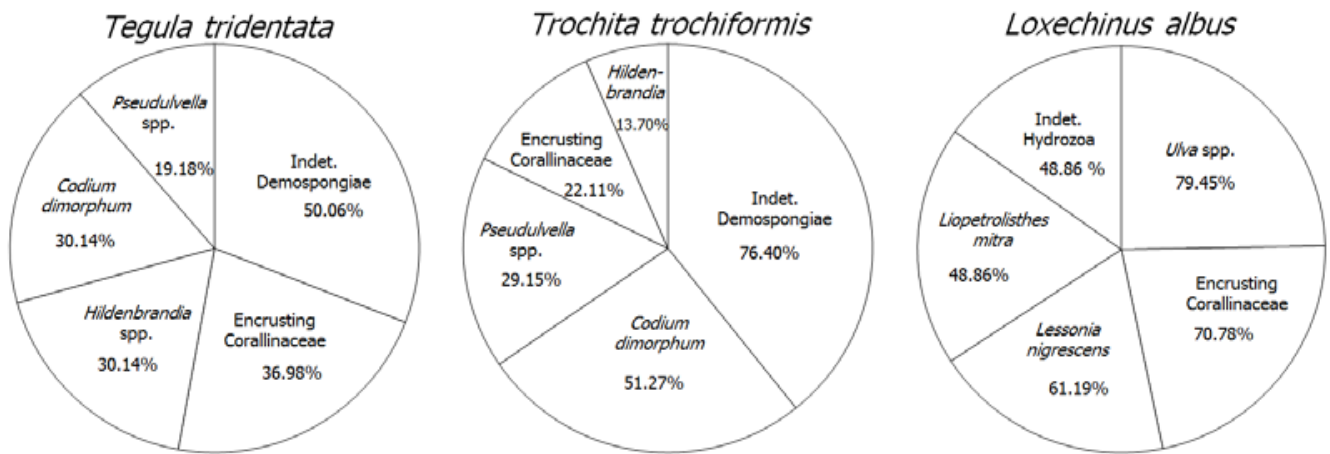

Tetrapygus niger

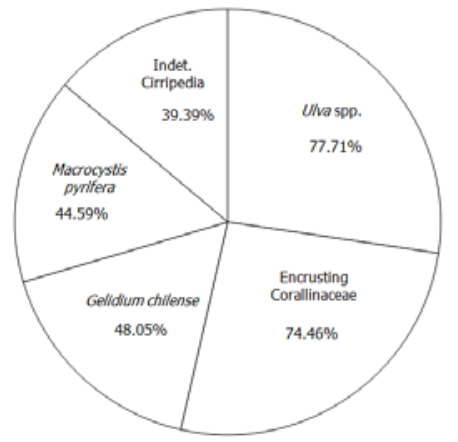

Heliaster helianthus
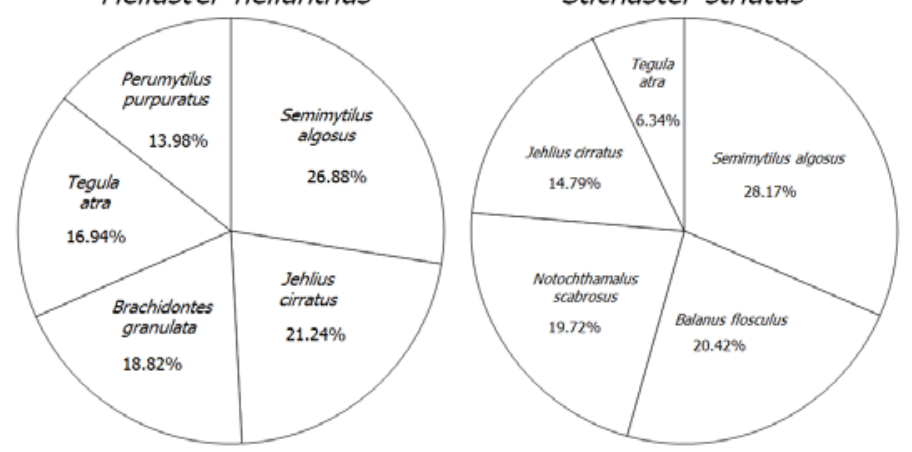

Figure 3. Circle graphs representing the proportional importance of the 5 preys ingested in highest frequency by each consumer species. Values: occurrence frequency of prey, obtained by pooling data from $\mathbf{1 2}$ seasonal samplings in $\mathbf{4}$ sites / Gráficos circulares representando la importancia proporcional de las 5 presas ingeridas con mayor frecuencia por cada especie consumidora. Valores: frecuencia de ocurrencia de las presas, obtenida agrupando los datos de 12 muestreos estacionales en 4 sitios 
striatus (Table 1). However, both the diet range and the within-individual component of diet width were much higher for $H$. helianthus than S. striatus (Table 1), which may reflect actual differences in their diet and trophic behavior. The clustering of trophic omnivores (Fig. 2) did not show a clear taxonomic pattern for species belonging to the same genus or class, and the species located most distant from the cluster's center (such as S. scurra, L. albus, T. niger, O. maginata, $P$. niger and $F$. cumingi) were those showing extreme or contrasting values for the variables described in previous paragraphs. However, the importance of body size and degree of omnivory was reflected by the relative ordination of consumers along the major cluster axis, with the largest, most omnivorous species and the smallest, most herbivorous ones located, respectively, toward the upper-left and lower-right sectors (Fig. 2). In this context, an inspection of Tables 1 and 2 reinforces the idea that taxonomic relatedness might be little important for explaining the similarities (or differences) among consumer diets.

The eventually low effect of taxonomic relatedness is also reflected by Fig. 3, which shows a series of circle graphs representing the proportional importance of the five preys most frequently ingested by each consumer. Barnacles, mussels and the snail $T$. atra were the most frequent preys of the carnivores $H$. helianthus and $S$. striatus, although the relative importance of prey species was different for the two starfish. For the remaining species, Fig. 3 makes clear that despite important variations in the identity and frequency of their commonest prey, the majority of consumers shared some particular preys to a large extent. The five prey items most often co-used by non-carnivorous species were Codium dimorphum (Chlorophyta; shared by $75.0 \%$ of consumers), Hildenbrandia spp. (Rhodophyta; 75.0\%), encrusting Corallinaceae (Rhodophyta; 60.7\%), Ulva spp. (Chlorophyta; 46.4\%) and Pseudulvella sp. (Chlorophyta; 42.9\%), and all of them but Ulva corresponded to fleshy or calcified algae of encrusting habit.

\section{Discussion}

Rocky intertidal consumers in northern Chile formed a heterogeneous assemblage, including a large core of common species with high spatiotemporal levels of occurrence and several species irregularly present in the study sites. Similarly, an important core of their prey species was consumed in consistently high frequency in time and space, but others remained highly variable, which explains why many consumers' diets appear similar at an overall level, while the number and frequency of preys in their gut contents may still show a high variation within and/or between sites. A number of physical and chemical variation sources on northern Chile, including coastal upwelling and El Niño-Southern Oscillation (see review by Thiel et al. 2007), may strongly influence the occurrence of species from local to regional scales, resulting in high replacement levels. As shown elsewhere (Camus 2008a), each of these communities exhibits a high temporal turnover in the composition of detectable macroscopic species (including consumers and preys), reaching in average up to $40-50 \%$ from one season to another. Such dynamical scenario highlights the importance of treating diet as a variable instead of a property of a given population or species.

The consumer assemblage included also a suite of large-sized polyphagous species which, as a whole, would exert a strong consumption pressure on virtually all types of organisms that can be found on rocky substrata, emphasizing the importance of further manipulative experiments evaluating the actual consumption rates. Albeit our dietary study did not include all existing consumers in northern Chile, the negative relation found between body size and density suggests the possibility of an underlying scaling relationship, as previously shown in central Chile (Marquet et al. 1990), which should be explored in regard with processes influencing resources availability, resource allocation and energy use among species (see White et al. 2007).

During our low-tide daytime samplings, most species showed a patchy distribution and several occurred in dense aggregations, as reflected by their large differences between minimum and maximum densities, although their spatial behavior under different conditions has not been studied. Recent analyses in central Chile on C. granosus, F. crassa, Scurria araucana and Siphonaria lessoni showed that, depending on the species, aggregations may be formed during low and/or high tides as well as during resting and/or foraging periods, but also that some species display a positive spatial association when foraging (see Aguilera \& Navarrete 2011). However, as northern and central Chile have different climatic/oceanic regimes (Thiel et al. 2007), the characteristics and physiological effects of aggregation might depend on the spatial environmental variation along the coast (e.g., as shown for the periwinkle Echinolittorina peruviana; Rojas et al. 2000, Muñoz et al. 2008), and the possibility that consumers display a geographically consistent behavior remains to be evaluated (e.g., see Sanford 1999, 

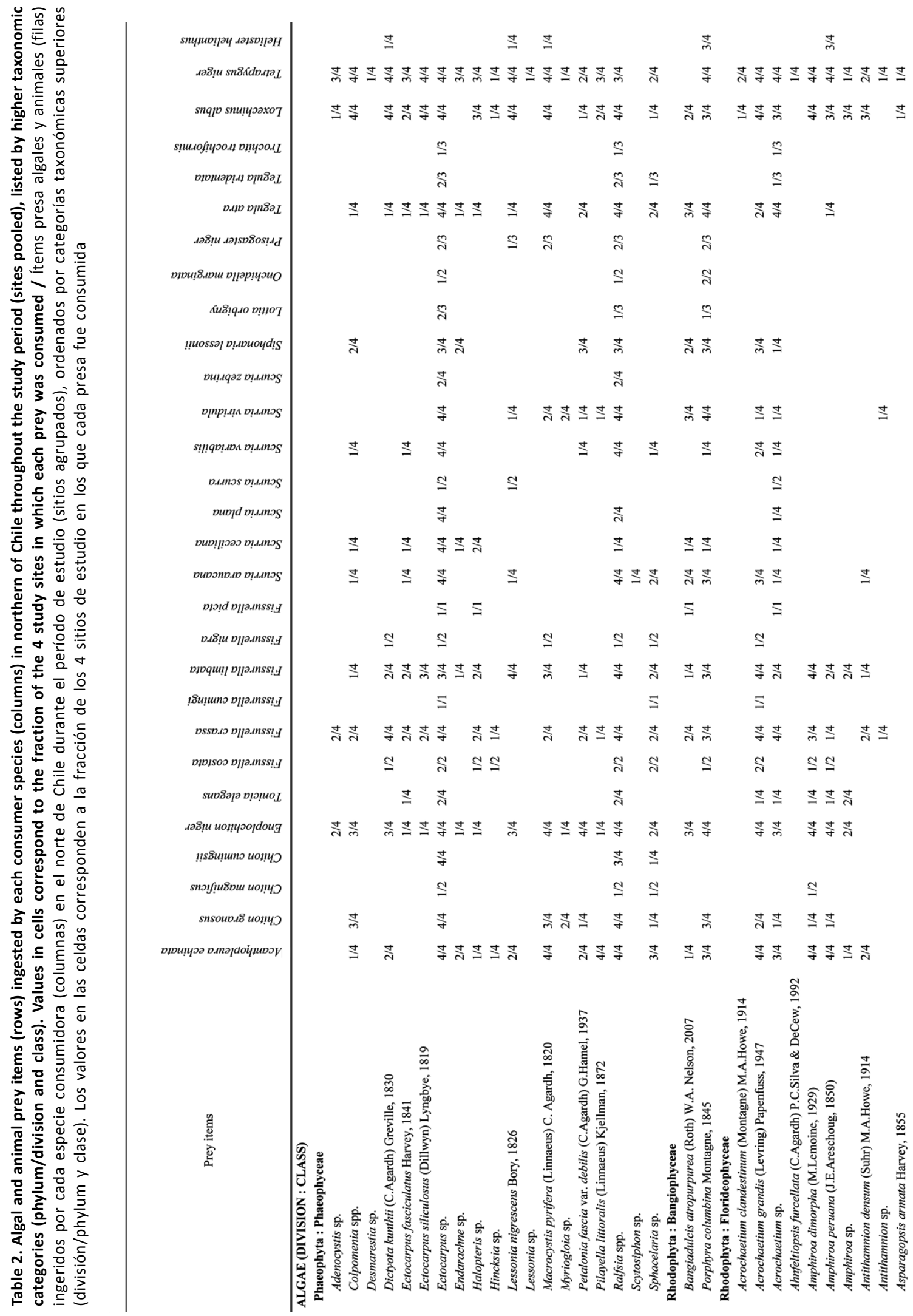

Vol. 48, № 3, 2013 


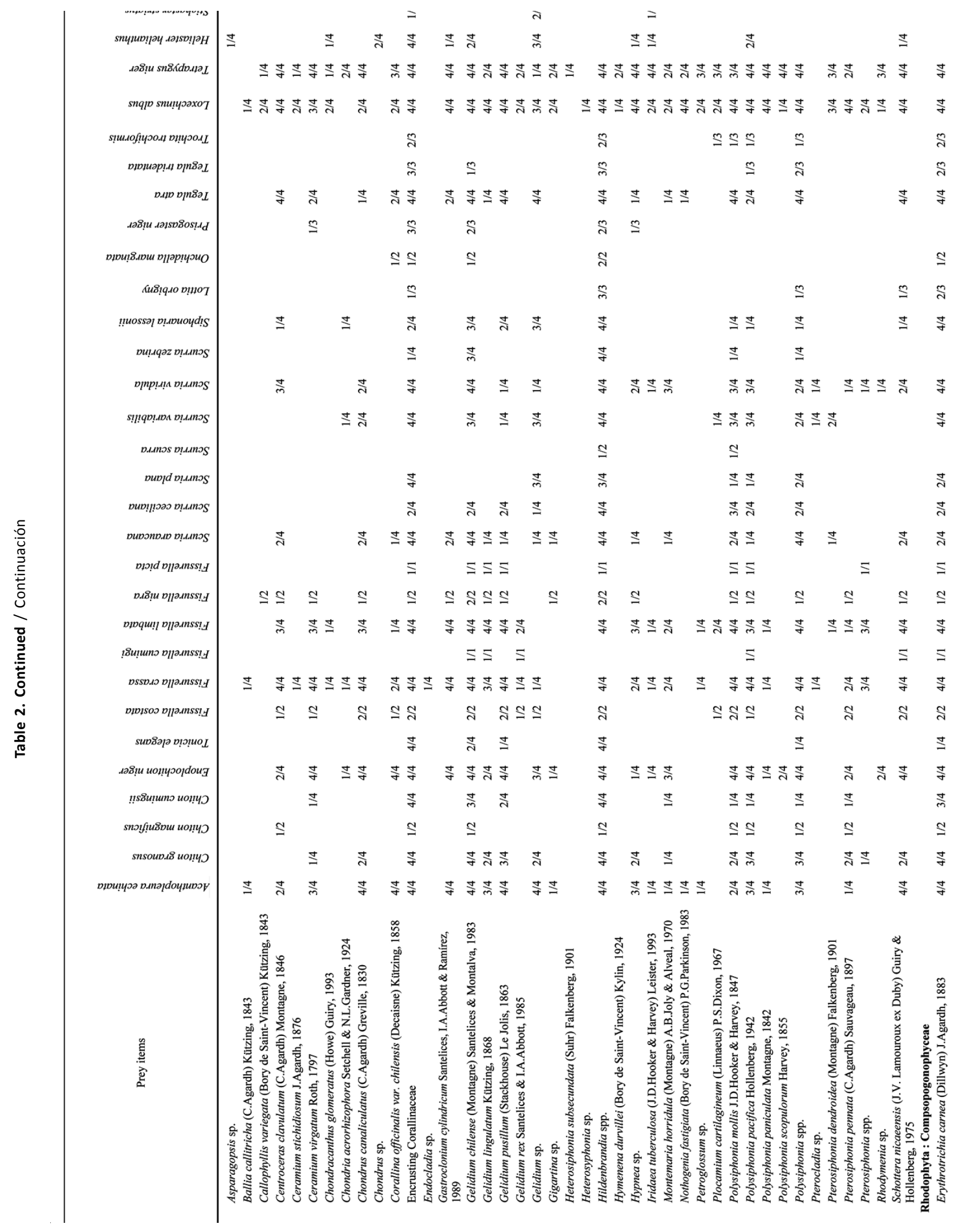

442 Camus et al.

Rocky intertidal consumers 


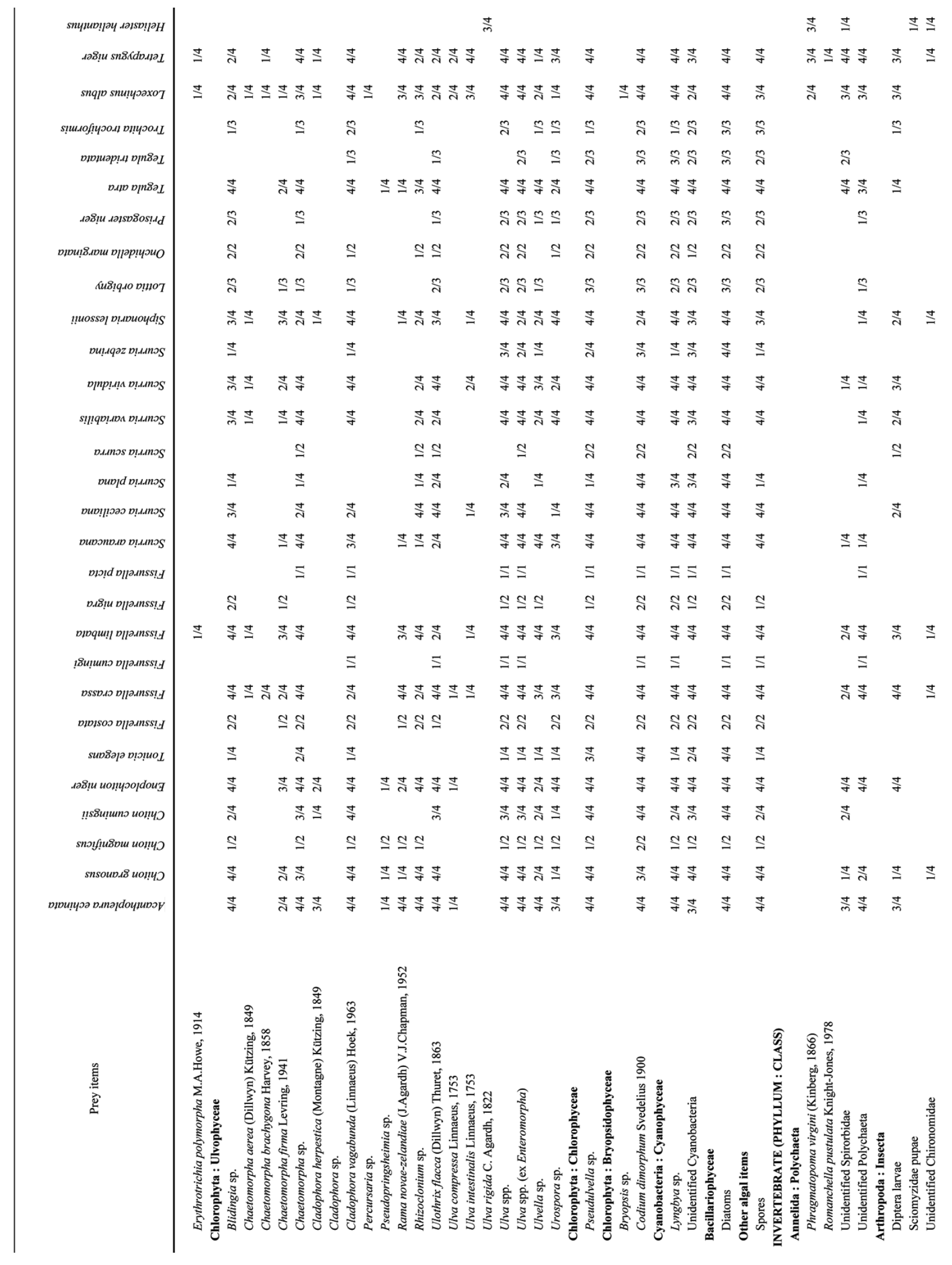




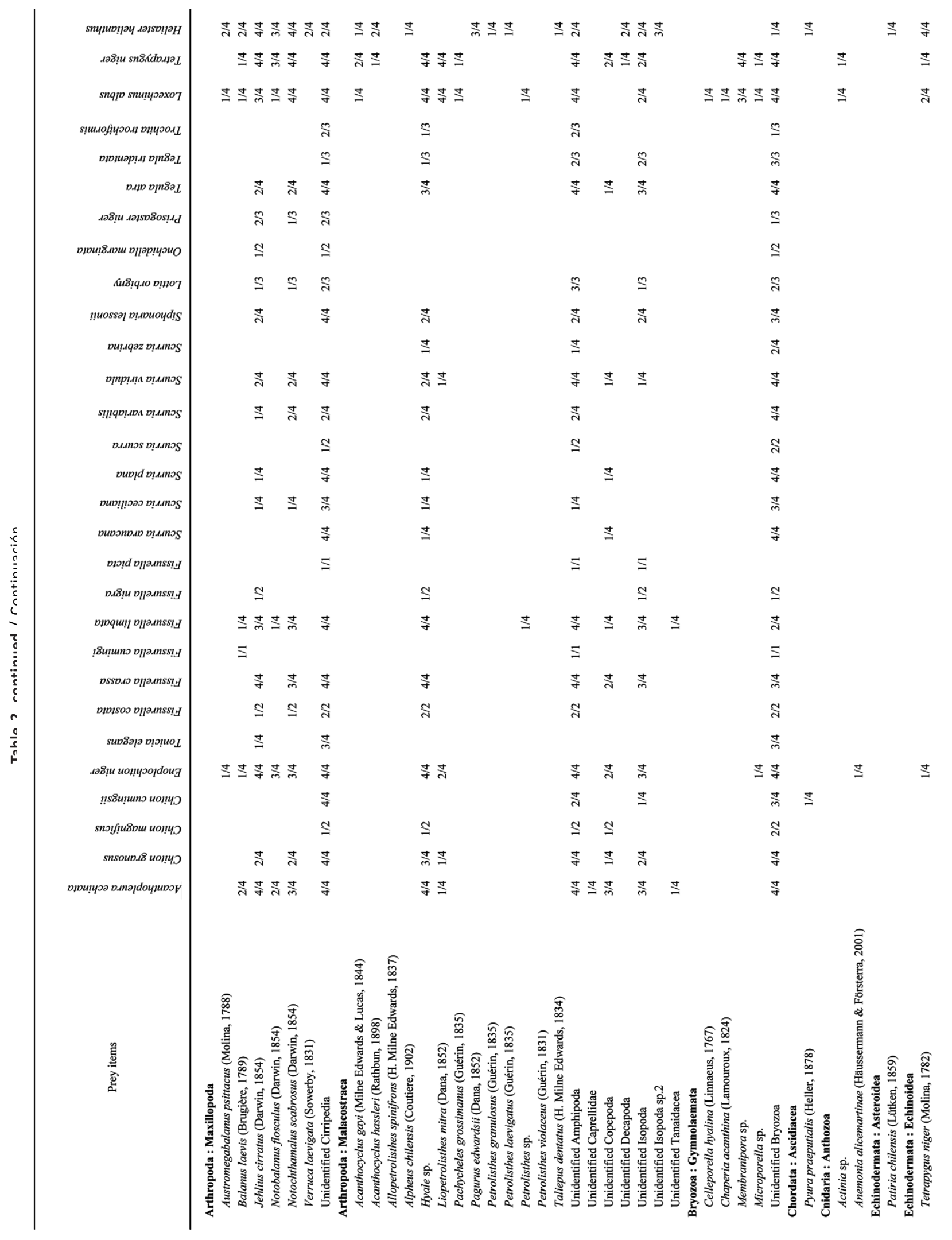




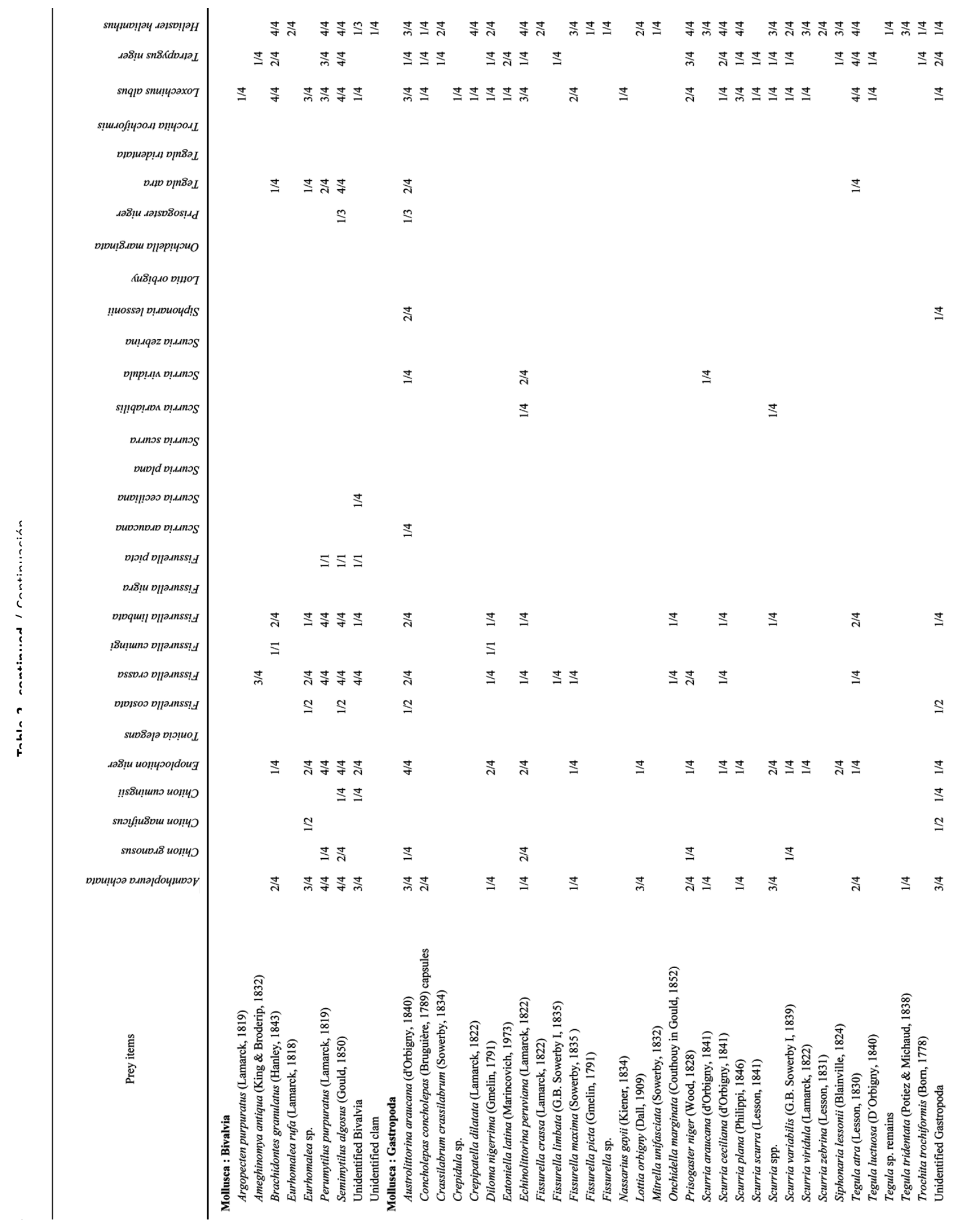




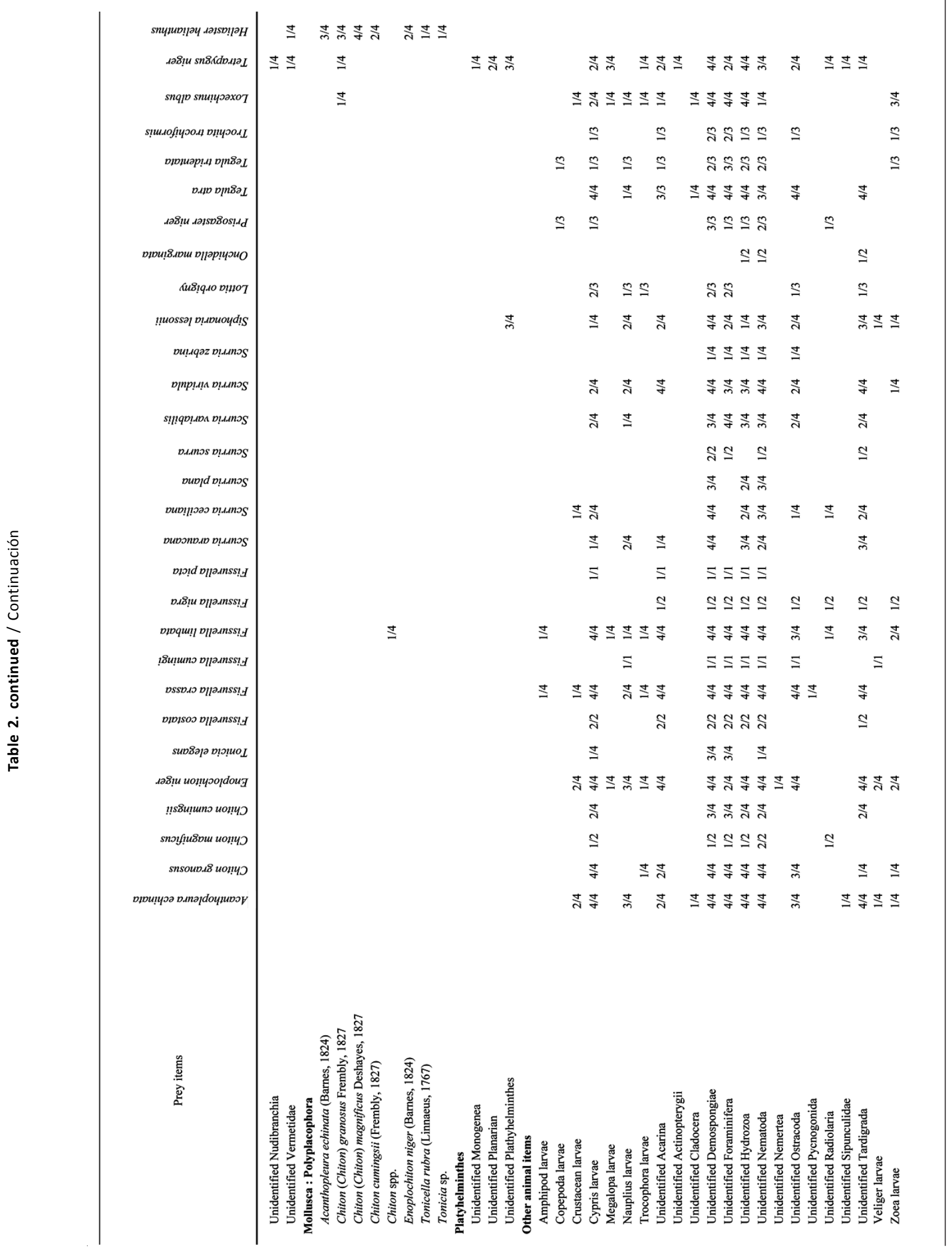


Navarrete \& Manzur 2008). More importantly, the similarity in diet among northern Chilean consumers suggests that, if they eventually form inter-specific associations and/or aggregations when foraging, they might exert very strong impacts on prey species at small spatial scales. In this regard, encrusting algae (Codium, Hildenbrandia, Pseudulvella, Corallinaceae) and Ulva spp. were the commonest and most frequently shared prey of the majority of non-carnivore consumers (see also Navarrete et al. 2008, Sanhueza et al. 2008, Camus et al. 2012), a fact deserving further consideration. In most cases, the importance of these items in gut contents might be explained by their commonness in northern Chilean assemblages, where algae such as Ulva rigida and Hildenbrandia lecanellieri are core species (sensu Hanski 1982) on a geographical scale (i.e., occurring in $>$ $90 \%$ of sites and showing the highest mean local coverage; see Camus 2008b). While Codium dimorphum is much more common in central than northern Chile, our community survey (Camus et al., unpublished data) showed that despite it did not reach a measurable coverage in Iquique, its mean local coverage (when present) was 5\% in Antofagasta and 12\% in Huasco and Coquimbo, being indeed available to consumers. It is also likely that the consumption of $C$. dimorphum is enhanced by its encrusting habit and the high edibility of its soft fleshy thallus, as suggested by the intense grazing on this species in central Chile (Santelices 1987). As noted in a prior work that included Antofagasta and Coquimbo (Camus \& Andrade 1999), typical macroscopic samplings tend to underestimate the importance of several smallsized, juvenile and encrusting algal forms, which occur mostly below and among other larger or erect sessile species, but are consumed in high frequency by grazers, giving the impression of being over-represented in gut contents. In addition, the wide and polyphagous diet of most consumers might be enhanced by the encrusting habit or widespread occurrence of their core algal preys, as grazers likely bulldoze a wide variety of algal and animal items found on the surface and neighbourhood of the algae (including microalgae and larval or early stages). On the other hand, it must be noted that the causes of the dominant presence of encrusting algae in gut contents are not entirely clear so far. Consumers may regularly ingest these algae because of their nutritional importance, or as a consequence of bulldozing their surface while targeting on other preys, or for both reasons (for a general discussion on this subject see Aguilera 2011). In whatever case, such causes should be investigated separately for each consumer species, taking into account that radular morphology may not be a good predictor of feeding patterns, that the widespread ingestion of animal items may have important physiological and ecological consequences (as discussed elsewhere; Camus et al. 2008), and the fact that we still know very little about the actual food items from which consumers' digestive processes ultimately extract nutrients (e.g., see Raffaelli 1985, Greese 1988, Camus et al. 2009, 2012). In addition, our daytime low-tide samples reveal that remarkably few of the 6,733 analyzed individuals (and from only nine species) had empty digestive tracts, suggesting that feeding excursions are more frequent than previously thought. Our prior studies (Camus et al. 2009) and laboratory observations in F. picta, F. limbata, C. granosus and $T$. niger, indicate that the rate of food passage through their digestive tracts might vary from 6 to $14 \mathrm{~h}$, which is high enough as to stimulate the acquisition of new food in the short term (and low enough as to allow a proper detection of food items in gut contents). Thus, a detailed knowledge of the spatial and temporal overlap among consumers species is key to assess their potential for exploitative and interference competition, as examined in central Chile (Aguilera \& Navarrete 2011).

In regard with intra- vs. inter-specific dietary differences, we remark that our results should be interpreted with caution and in relative terms, considering some methodological and ecological issues. For instance, prey ranges at the species level are often (though not always) widened by the pooling of individual data and the high resolution of diets, causing that few consumers appear specialized. In contrast, individuals provide fixed information mostly reflecting their recent, short-term foraging activities within their home range, which may tend to overestimate individual specialization and between-individual diversity, especially if resource patchiness is high (Bolnick et al. 2002, Layman \& Post 2008). Consequently, as the number of collected individuals correlates with the natural occurrence of consumers, more common species provide larger samples tending to appear more generalized and with a higher degree of individual specialization (for a discussion on sampling effects and related aspects, see Bolnick et al. 2002, 2007). In such context, some consumers in northern Chile might be hypothesized as fully specialists or generalists because their prey ranges were, respectively, consistently narrow (e.g., S. striatus, T. tridentata) or wide (e.g., L. albus) both at the species and individual level. However, other consumers (e.g., C. granosus, E. niger, P. niger, S. lessoni, Scurria viridula, T. atra) had a 
small diet breadth at the individual level (low withinindividual diversity; Bolnick et al. 2002) but, as an effect of pooling individual diets, appeared as generalists at the species level. While the expansion of the population niche is usually considered a result of increasing withinindividual diversity (individuals become generalized), but it may also occur by increasing between-individual diversity, when individuals remain specialized but tend to use different resource states (e.g., if functional tradeoffs limit the abilities of individuals to widen their prey range; see Bolnick et al. 2007, 2010), as proposed by the niche variation hypotheses (Van Valen 1965). Such processes are poorly known in Chilean rocky shores, and our results highlight two potentially important aspects requiring further investigation. First, even though northern Chilean consumers show varying levels of within- and betweenindividual diversity, some generalist species may be actually formed by specialized rather than generalized individuals. However, little attention has been paid to the ecological and evolutionary significance of interindividual variations in resource use, which may relate to a diverse array of factors including differences in sex, age, physiology, morphology and animal personality (for a review, see Dall et al. 2012). Furthermore, it is important to note that variations in niche width at population and individual levels may be decoupled and also follow different patterns in different species (Bolnick et al. 2010), which might help to explain the apparently idiosyncratic patterns of some northern Chilean consumers. Second, trophic omnivores, especially those of larger body size, have very similar diets at the species level and their most frequent preys tend to be the same, but the existence or extent of resource limitation and competition in these assemblages remain largely unexplored. In northern Chile, for instance, the proportion of animal items consumed by A. echinata decreases with body size (Camus et al. 2012), suggesting ontogentic variations in diet as larger individuals become more herbivorous. In central Chile, several studies on C. granosus, F. crassa, S. araucana and $S$. lessoni, show some differences in activity rhythm and homing behavior pattern (orientation and displacement length) among their individuals, and also indicate that, depending on the species, interference competition may be important among either conspecific or heterospecific individuals (Aguilera \& Navarrete 2007, 2011), as it was recently confirmed (Aguilera \& Navarrete 2012). However, our view of these phenomena may be inaccurate if approached only from aggregated (population or species) levels, and the role of withinpopulation variation should not be disregarded as individual specialization might be effective in reducing intra- and inter-specific competition.

While Chilean rocky intertidal food webs might not have a higher complexity than those of other marine or continental environments (see Dunne et al. 2004, Thompson et al. 2007), they are certainly much more complex than previously thought (Camus et al. 2008, 2012). Our data show that most consumers are omnivores linked to a very high number of predators and preys of varying trophic positions, often connecting to top and basal species simultaneously and likely engaged in complex intraguild interactions (see Camus et al. 2008). Such combination of intricate structure and high connectivity, along with the potential role of body size and individual behavior, may be key for understanding the functioning and stability of these food webs (Neutel et al. 2002, Berlow et al. 2008, Petchey et al. 2008).

\section{AcKnowledgments}

We thank financial support from CONICYT, Chile (grant FONDECYT 1040425), and Dirección de Investigación UCSC (grant FAA 2-2012). We are grateful to Karen Daroch, Daniela López, Christian Ibáñez, Arturo Navarrete and Felipe Opazo for field and laboratory assistance. We also thank the valuable and constructive comments made by two anonymous reviewers. P.A. Arancibia and M.I. Ávila-Thieme thank financial support (Tuition remission, Stipend and Teaching assistance fellowships)from Programa de Magíster en Ecología Marina, Facultad de Ciencias, UCSC.

\section{LITERATURE CITED}

Aguilera MA. 2005. Cirripedios en la dieta del molusco herbívoro Chiton granosus Frembly 1827 (Mollusca: Placophora) presente en el intermareal rocoso de Chile. Investigaciones Marinas 33: 109-113.

Aguilera MA. 2011. The functional roles of herbivores in the rocky intertidal systems in Chile: A review of food preferences and consumptive effects. Revista Chilena de Historia Natural 84: 241-261.

Aguilera MA \& SA Navarrete. 2007. Effects of Chiton granosus (Frembly, 1827) and other molluscan grazers on algal succession in wave exposed mid-intertidal rocky shores of central Chile. Journal of Experimental Marine Biology and Ecology 349: 84-98.

Aguilera MA \& SA Navarrete. 2011. Distribution and activity patterns in an intertidal grazer assemblage: influence of temporal and spatial organization on interspecific associations. Marine Ecology Progress Series 431: 119136. 
Aguilera MA \& SA Navarrete. 2012. Interspecific competition for shelters in territorial and gregarious intertidal grazers: Consequences for individual behaviour. PLOS ONE 7: e46205.

Appeltans W, P Bouchet, GA Boxshall, C De Broyer, NJ de Voogd, DP Gordon, BW Hoeksema, T Horton, M Kennedy, J Mees, GCB Poore, G Read, S Stöhr, TC Walter \& MJ Costello. 2013. World Register of Marine Species. < http://www.marinespecies.org>

Bolnick DI, LH Yang, JA Fordyce, JM Davis \& R Svanbäck. 2002. Measuring individual-level resource specialization. Ecology 83: 2936-2941.

Berlok EL, U Brose \& ND Martinez. 2008. The 'Goldilocks factor' in food webs. Proceedings of the National Academy of Sciences of the United States of America 105: 40794080.

Bolnick DI, R Svanbäck, MS Araújo \& L Persson. 2007. Comparative support for the niche variation hypothesis that more generalized populations also are more heterogeneous. Proceedings of the National Academy of Sciences of the United States of America 104: 10075-10079.

Bolnick DI, T Ingram, WE Stutz, LK Snowberg, OL Lau \& JS Paull. 2010. Ecological release from interspecific competition leads to decoupled changes in population and individual niche width. Proceedings of the Royal Society B 277: 1789-1797.

Broitman BR, SA Navarrete, F Smith \& SD Gaines. 2001. Geographic variation of southeastern Pacific intertidal communities. Marine Ecology Progress Series 224: 21-34.

Camus PA. 2008a. Understanding biological impacts of ENSO on the eastern Pacific: An evolving scenario. International Journal of Environment and Health 2: 5-19.

Camus PA. 2008b. Diversidad, distribución y abundancia de especies en ensambles intermareales rocosos. Revista de Biología Marina y Oceanografía 43: 615-627.

Camus PA \& YN Andrade. 1999. Diversidad de comunidades intermareales rocosas del norte de Chile: el supuesto del enriquecimiento por efecto de la surgencia costera. Revista Chilena de Historia Natural 72: 389-410.

Camus PA, K Daroch \& LF Opazo. 2008. Potential for omnivory and apparent intraguild predation in rocky intertidal herbivore assemblages from northern Chile. Marine Ecology Progress Series 361: 35-45.

Camus PA, YY Cid, L Cisterna \& CW Cáceres. 2009. Consumption and digestion of animal food by rocky intertidal herbivores: An evaluation of digestive flexibility and omnivory in three grazer species. Latin American Journal of Aquatic Research 37: 191-197.

Camus PA, AH Navarrete, AG Sanhueza \& LF Opazo. 2012. Trophic ecology of the chiton Acanthopleura echinata on Chilean rocky shores. Revista Chilena de Historia Natural 85: 123-135.
Castilla JC \& RT Paine. 1987. Predation and community organization on Eastern Pacific, temperate zone, rocky intertidal shores. Revista Chilena de Historia Natural, 60: 131-151.

Dall SRX, AM Bell, DI Bolnick \& FLW Ratnieks. 2012. An evolutionary ecology of individual differences. Ecology Letters 15: 1189-1198.

Dunne JA, RJ Williams \& ND Martinez. 2004. Network structure and robustness of marine food webs. Marine Ecology Progress Series 273: 291-302.

Fernández M, E Jaramillo, PA Marquet, CA Moreno, SA Navarrete, FP Ojeda, CR Valdovinos \& JA Vásquez. 2000. Diversidad, dinámica y biogeografía del ecosistema costero bentónico de Chile: revisión y bases para conservación marina. Revista Chilena de Historia Natural 73: 797-830.

Grall J, F Le Loc'h, B Guyonnet \& P Riera. 2006. Community structure and food web based on stable isotopes $(\delta 15 \mathrm{~N}$ and $\delta 13 \mathrm{C}$ ) analysis of a North Eastern Atlantic maerl bed. Journal of Experimental Marine Biology and Ecology 338: 1-15.

Greese RG. 1988. Ecology of molluscan grazers and their interactions with marine algae in north-eastern New Zealand: a review. New Zealand Journal of Marine and Freshwater Research 22: 427-444.

Guiry MD \& GM Guiry. 2013. AlgaeBase. World-wide electronic publication, National University of Ireland, Galway. <http://www.algaebase.org>

Hanski I. 1982. Dynamics of regional distribution: the core and satellite species hypothesis. Oikos 38: 210-221.

Hughes AD, AI Catarino, MS Kelly, DKA Barnes \& KD Black. 2005. Gonad fatty acids and trophic interactions of the echinoid Psammechinus miliaris. Marine Ecology Progress Series 305: 101-111.

Latyshev NA, AS Khardin, SP Kasyanov \& MB Ivanova. 2004. A study in the feeding ecology of chitons using analysis of gut contents and fatty acid markers. Journal of Molluscan Studies 70: 225-230.

Layman CA \& DM Post. 2008. Can stable isotope ratios provide for community-wide measures of trophic structure? Reply. Ecology 89: 2358-2359.

López DA, ML González \& MC Pérez. 2003. Feeding and growth in the keyhole limpet, Fissurella picta (Gmelin, 1791). Journal of Shellfish Research 22: 165-169.

Marquet PA, SA Navarrete \& JC Castilla. 1990. Scaling population-density to body size in rocky intertidal communities. Science 250: 1125-1127.

Muñoz JLP, PA Camus, FA Labrab, GR Finke \& F Bozinovic. 2008. Thermal constraints on daily patterns of aggregation and density along an intertidal gradient in the periwinkle Echinolittorina peruviana. Journal of Thermal Biology 33: 149-156. 
Navarrete AH, PA Camus \& LF Opazo. 2008. Variación ambiental y patrones dietarios del erizo negro Tetrapygus niger en costas intermareales rocosas del norte de Chile. Revista Chilena de Historia Natural 81: 305-319.

Navarrete SA \& JC Castilla. 2003. Experimental determination of predation intensity in an intertidal predator guild: dominant versus subordinate prey. Oikos 100: 251-262.

Navarrete SA \& T Manzur. 2008. Individual- and populationlevel responses of a keystone predator to geographic variation in prey. Ecology 89: 2005-2018.

Navarrete SA, B Menge \& BA Daley. 2000. Species interactions in intertidal food webs: prey or predation regulation of intermediate predators? Ecology 81: 22642277.

Neutel AM, JAP Heesterbeek \& PC de Ruiter. 2002. Stability in real food webs: weak links in long loops. Science 296: 1120-1123.

Petchey OL, AP Beckerman, JO Riede \& PH Warren. 2008. Size, foraging, and food web structure. Proceedings of the National Academy of Sciences of the United States of America 105: 4191-4196.

Pimm SL \& JH Lawton. 1978. On feeding on more than one trophic level. Nature 275: 542-544.

Osorio C, ME Ramírez \& J Salgado. 1988. Gastric contents of Fissurella maxima (Mollusca: Archaeogastropoda) at Los Vilos, Chile. Veliger 30: 347-350.

Polis GA. 1991. Complex trophic interactions in deserts: an empirical critique to food-web theory. The American Naturalist 138: 123-155.

Raffaelli D. 1985. Functional feeding groups of some intertidal molluscs defined by gut contents analysis. Journal of Molluscan Studies 51: 233-240.

Rojas JM, JM Fariña, RE Soto \& F Bozinovic. 2000. Variabilidad geográfica en la tolerancia térmica y economía hídrica del gastrópodo intermareal Nodilittorina peruviana (Gastropoda: Littorinidae, Lamarck, 1822). Revista Chilena de Historia Natural 73: 543-552.

Sanford E. 1999. Regulation of keystone predation by small changes in ocean temperature. Science 283: 2095-2097.
Sanhueza AG, AH Navarrete, LF Opazo \& PA Camus. 2008. Caracterización trófica del placóforo intermareal Enoplochiton niger en el norte de Chile: variación ambiental y patrones dietarios a nivel local y regional. Revista Chilena de Historia Natural 81: 533-546.

Santelices B. 1989. Algas marinas de Chile, 399 pp. Ediciones Universidad Católica de Chile, Santiago.

Santelices B. 1987. Marine herbivory studies. The South American contribution. Revista Chilena de Historia Natural 60: 153-158.

Santelices B \& JA Correa. 1985. Differential survival of macroalgae to digestion by intertidal herbivore molluscs. Journal of Experimental Marine Biology and Ecology 88: 183-191.

Santelices B, J Vásquez \& I Meneses. 1986. Patrones de distribución y dietas de un gremio de moluscos herbívoros en hábitats intermareales expuestos de Chile central. En: Santelices B (ed). Usos y funciones ecológicas de las algas marinas bentónicas. Monografías Biológicas 4: 147-175. Ediciones Universidad Católica de Chile, Santiago.

Thiel M, E Macaya, E Acuña, W Arntz, H Bastias, K Brokordt, PA Camus, JC Castilla, LR Castro, M Cortés, CP Dumont, R Escribano, M Fernandez, DA Lancellotti, JA Gajardo, CF Gaymer, I Gomez, AE González, HE González, PA Haye, JE Illanes, JL Iriarte, G LunaJorquera, C Luxoro, PH Manriquez, V Marín, P Muñoz, SA Navarrete, E Perez, E Poulin, J Sellanes, A Sepúlveda, W Stotz, F Tala, A Thomas, CA Vargas, JA Vasquez \& A Vega. 2007. The Humboldt Current System of northern-central Chile: oceanographic processes, ecological interactions and socio-economic feedback. Oceanography and Marine Biology: An Annual Review 45: 195-345.

Thompson RM, M Hemberg, BM Starzomski \& JB Shurin. 2007. Trophic levels and trophic tangles: the prevalence of omnivory in real food webs. Ecology 88: 612-617.

Van Valen L. 1965. Morphological variation and width of ecological niche. American Naturalist 99: 377-389.

White EP, SK Morgan-Ernest, AJ Kerkhoff \& BJ Enquist. 2007. Relationships between body size and abundance in ecology. Trends in Ecology and Evolution 22: 323-330.

Received 1 March 2013 and accepted 10 July 2013

Associate Editor: Alejandro Pérez Matus 